\title{
Geochemical and isotopic constraints on the petrogenesis of Early Ordovician granodiorite and Variscan two-mica granites from the Gouveia area, central Portugal
}

\author{
A.M.R. Neiva ${ }^{\text {a,* }}{ }^{\text {, I.S. Williams }}{ }^{\text {b }}$, J.M.F. Ramos ${ }^{c}$, M.E.P. Gomes ${ }^{\text {d }}$, M.M.V.G. Silva ${ }^{\text {a }}$, I.M.H.R. Antunes ${ }^{\text {e }}$ \\ a Department of Earth Sciences, University of Coimbra, 3000-272 Coimbra, Portugal \\ b Research School of Earth Sciences, The Australian National University, Canberra, ACT, 0200, Australia \\ ' INETI, Apartado 1089, 4466-956 S. Mamede de Infesta, Portugal \\ d Department of Geology, University of Trás-os-Montes e Alto Douro, 5000-911 Vila Real, Portugal \\ e Polytechnic Institute of Castelo Branco, 6000-919 Castelo Branco, Portugal
}

\section{A R T I C L E I N F O}

\section{Article history:}

Received 27 January 2008

Accepted 16 January 2009

Available online $\mathrm{xxxx}$

\section{Keywords:}

Granite

Geochronology

Geochemistry

Isotopes

Tin

Fractional crystallization

\begin{abstract}
A B S T R A C T
A biotite granodiorite and seven Sn-bearing two-mica granites crop out in the Gouveia area, central Portugal. A SHRIMP U-Th- $\mathrm{Pb}$ zircon age from the granodiorite, and monazite ages from four of the two-mica granites, show that they are of Early Ordovician ( $480 \mathrm{Ma})$ and Permo-Carboniferous, i.e. Variscan ( 305 and $290 \mathrm{Ma})$ age respectively. The Variscan two-mica granites are late- and post-D3. Major and trace element variation in the granitic rocks and their biotite and muscovite indicate mainly individual fractionation trends. The granitic rocks are mostly depleted in HREE relative to LREE. The biotite granodiorite is probably derived from igneous lower crust, as evidenced by low initial ${ }^{87} \mathrm{Sr} /{ }^{86} \mathrm{Sr}(0.7036)$, high $\varepsilon \mathrm{Nd}_{\mathrm{T}}(+2.5)$ and moderate $\delta^{18} \mathrm{O}(8.8 \%)$. The two-mica granites are probably derived by partial melting of heterogeneous mid-crustal metasediments, mainly metapelite and some metagraywacke, as evidenced by their high initial ${ }^{87} \mathrm{Sr} /{ }^{86} \mathrm{Sr}(0.7076-0.7174)$, $\delta^{18} \mathrm{O}(10.7-13.4 \%$ ) and major element compositions. However, variation diagrams for major and trace elements from two of the muscovite> biotite granites and their micas define fractionation trends. $\mathrm{Rb}-\mathrm{Sr}$ whole-rock analyses from the two granites are perfectly fitted to a single isochron and the rocks have subparallel REE patterns; the younger granite is derived from the older by fractional crystallization of quartz, plagioclase, biotite and ilmenite (tested by modelling major and trace elements). Most of the Sn-bearing granites are derived from distinct magma batches. They result from partial melting of a heterogeneous midcrustal metasediment. They do not represent a crustal anomaly in tin. Fractional crystallization is responsible for the increase in the Sn contents of the granites and their micas. Muscovite has a higher Sn content than coexisting biotite and is the principal host mineral for $\mathrm{Sn}$ in these rocks.
\end{abstract}

(c) 2009 Elsevier B.V. All rights reserved.

\section{Introduction}

The Gouveia area lies within the Central Iberian Zone, which is the innermost zone of the Iberian Massif. This massif corresponds to the south-western extension of the European Variscan Belt. Large volumes of granitic rocks were emplaced in the region, mainly during the third Variscan deformation D3 from 320 to 300 Ma (Dias et al., 2002), which generated multiple subvertical strike-slip shear zones (Valle Aguado et al., 2005). At lower crustal levels, the high temperatures possibly resulted from high thermal gradients from D2 and syntectonic granitoid intrusions. At higher crustal levels D3 occurred under greenschist facies retrograde conditions (e.g. Abalos et al., 2002). Many of the Variscan granitoids are significantly enriched in Sn. Some early plutonic rocks in the Central Iberian Zone, with ages between 500 and 455 Ma, predate the Variscan orogeny (Zeck et al, 2007).

\footnotetext{
* Corresponding author. Tel.: +351 239 860500; fax: +351 239860501 E-mail address: neiva@dct.uc.pt (A.M.R. Neiva).
}

Unaltered Sn-bearing granites commonly contain 18-26 ppm Sn (Lehmann, 1990), four to five times more Sn than ordinary granites (3-5 ppm Sn, e.g. Lehmann, 1987; Solomon et al., 1994). Fractionation of S-type magmas increases their Sn contents (Lehmann, 1982; Neiva, 1984; Lehmann, 1990; Sawka et al., 1990; Blevin and Chappell, 1995; Neiva, 2002; Gomes and Neiva, 2002). In general, primary Sn and W deposits are derived from hydrothermal systems related to $\mathrm{Sn}$-bearing granites. Igneous cassiterite occurs only locally in a few granites (Haapala, 1997; Gomes and Neiva, 2002).

The granitic rocks from the Gouveia area range from granodiorite to granite. Some Variscan granites are cut by Sn-bearing granitic aplitepegmatite dykes and veins (Neiva et al., 2008), so it is important to characterize the parent granites and explain their Sn enrichment. This paper presents the geology, petrography, mineralogy, geochemistry and isotopic ( $\left.\mathrm{Rb}-\mathrm{Sr}, \mathrm{Sm}-\mathrm{Nd}, \delta^{18} \mathrm{O}, \mathrm{U}-\mathrm{Th}-\mathrm{Pb}\right)$ characteristics of the granitic rocks from the Gouveia area. Our aim was to date the emplacement of the granitic rocks, and to understand the mechanisms responsible for their origins, evolution and Sn enrichment. One outcome 
of our work was the discovery of an undeformed Early Ordovician granodiorite, a rarity in Portugal.

\section{Geology}

Granitic rocks, intruded into a Cambrian schist-metagraywacke complex, predominate in the Gouveia area (Fig. 1). Seven different Variscan two-mica granitoids have been identified (G2-G8), and also an Early Ordovician medium- to coarse-grained slightly porphyritic biotite granodiorite (G1) that crops out in the south around Manteigas. Three of the Variscan granitoids are late-D3; medium- to fine-grained porphyritic muscovite> biotite granite G2, medium-grained slightly porphyritic muscovite > biotite granite G3 and coarse- to very coarsegrained porphyritic biotite > muscovite granite G4. Four of the Variscan granitoids are post-D3; coarse-grained porphyritic muscovite $>$ biotite granodiorite to granite $\mathrm{G} 5$, medium- to coarse-grained slightly porphyritic muscovite > biotite granite G6, medium-grained muscovite > biotite granite $G 7$ and fine- to medium-grained slightly porphyritic biotite $\approx$ muscovite granite G8.

The Early Ordovician granodiorite has a hornfels contact metamorphic aureole. The Variscan granitoids mostly produced a contact metamorphic mica schist, but locally there is an inner zone of pelitic hornfels surrounded by mica schist. Most of the contacts between the granitic rocks are sharp (Table 1), but the granodiorite to granite G5 locally grades into granite G6. In general, the granites contain xenoliths of metasedimentary origin and rarely microgranular enclaves (Table 1 ).
The schist-metagraywacke complex and granitic rocks are cut by subvertical aplite and pegmatite veins and NE-SW, NNE-SSW and locally subvertical N-S and NW-SE trending quartz veins containing cassiterite and wolframite. The schist-metagraywacke complex and granites G4, G5, G6 and G8 are also cut by subhorizontal, mainly NWSE and NE-SW trending, Sn-bearing aplite-pegmatite dykes and veins. NE-SW and NNE-SSW trending faults cut the rocks and quartz veins.

\section{Petrography}

According to the classification of Le Maitre et al. (2003), most of the granitic rocks are granites sensu stricto. G1 and one sample of G5 are granodiorites. All the granitic rocks have a subhedral granular texture and most of them contain feldspar phenocrysts (Table 1). Some show the effects of deformation; quartz and feldspar have undulose extinction, micas are bent and quartz is fractured. Biotite granodiorite G1and the two-mica granites contain quartz, microperthitic microcline, plagioclase and biotite, but the latter also contain muscovite (Table 1 ).

Quartz contains inclusions of the minerals belonging to the mineral assemblage of the granite. Plagioclase and microcline compositions are given in Table 1 . Commonly biotite and muscovite are intergrown and host inclusions of zircon, apatite and ilmenite, but also of magnetite in biotite granodiorite $\mathrm{G} 1$, and of monazite in the two-mica granites. The micas in G1, G2, G3 and G4 show some preferred orientation. However, it decreases from G2 to G4 and is less marked in G1.
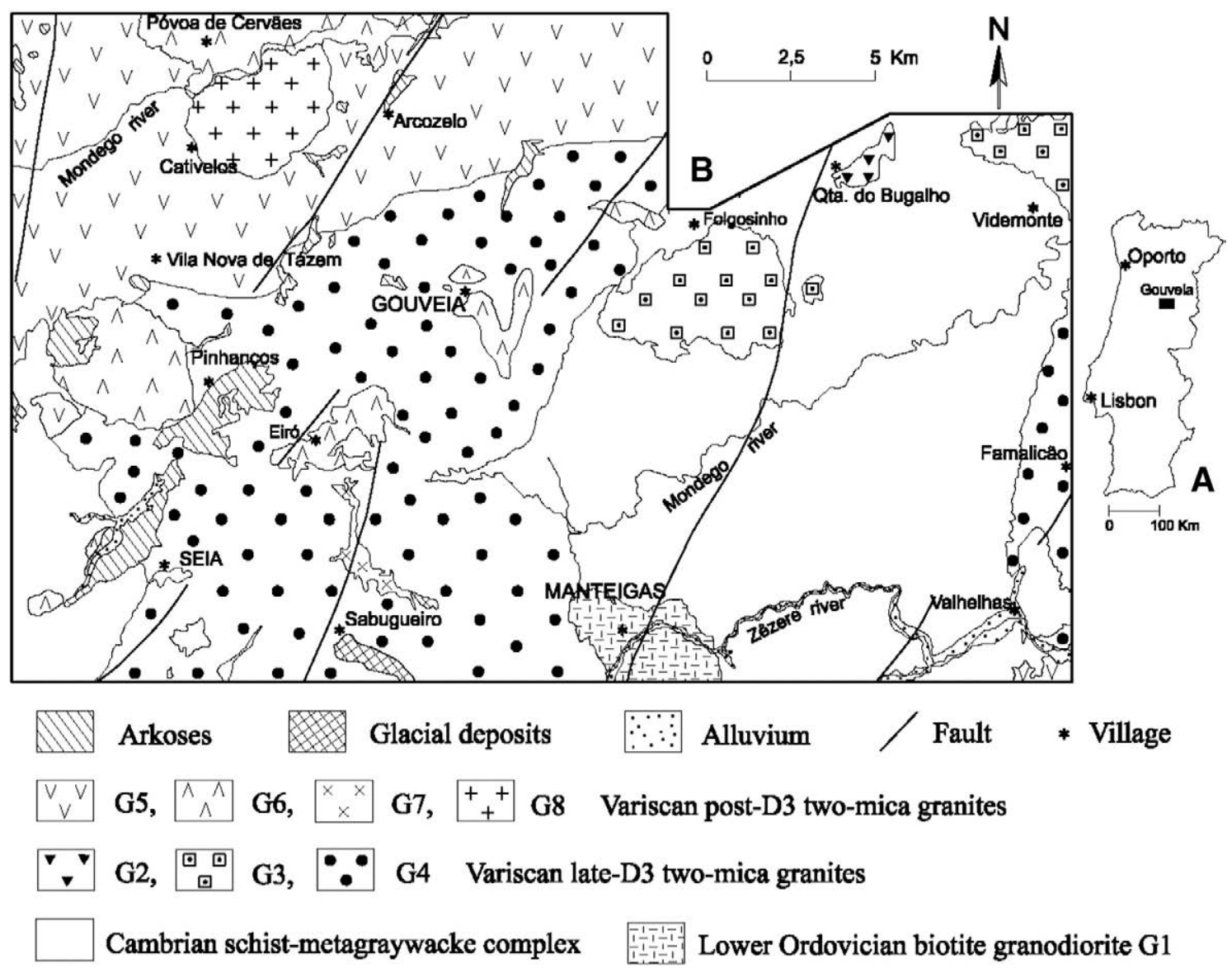

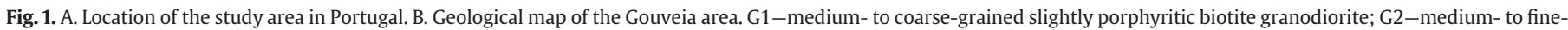

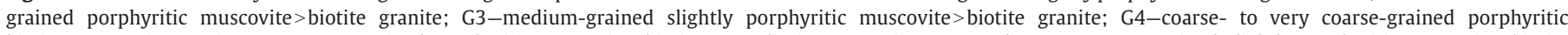

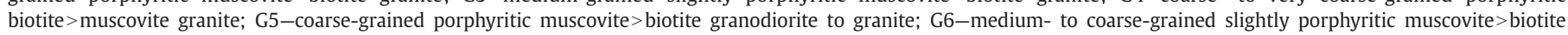
granite; G7-medium-grained muscovite>biotite granite; G8-fine- to medium-grained slightly porphyritic biotite $\approx$ muscovite granite. 
Table 1

Geological and petrographic informations on the granitic rocks from the Gouveia area, central Portugal

\begin{tabular}{|c|c|c|c|c|c|c|c|c|c|}
\hline \multicolumn{2}{|l|}{$\begin{array}{l}\text { Granitic rocks } \\
\text { Location }\end{array}$} & G1 Granodiorite & G2 Granite & G3 Granite & G4 Granite & G5 Granodiorite to granite & G6 Granite & G7 Granite & G8 Granite \\
\hline & $\begin{array}{l}\text { At } \mathrm{S} \text {, around } \\
\text { Manteigas }\end{array}$ & $\begin{array}{l}\text { At NE, close to } \mathrm{Qt}^{\mathrm{a}} \\
\text { do Bugalho }\end{array}$ & $\begin{array}{l}\text { At NE, } \mathrm{N} \text { of Videmonte } \\
\text { and } \mathrm{S} \text { of Folgosinho }\end{array}$ & $\begin{array}{l}\text { Predominates in the } \\
\text { central part Sabugueiro- } \\
\text { Gouveia and at E of } \\
\text { Famalicão; sharp contact } \\
\text { with G1 }\end{array}$ & $\begin{array}{l}\text { At N from Arcozelo to } \\
\text { Vila Nova de Tázem, } \\
\text { in contact with G4, } \\
\text { local contact by faults }\end{array}$ & $\begin{array}{l}\text { At N surrounding } \\
\text { Póvoa de Cervães, } \\
\text { W of Folgosinho, } \\
\text { W of Pinhanços, } \\
\text { N and SE of Gouveia, } \\
\text { Eiró, NW and WSW } \\
\text { of Seia; intruded G4, } \\
\text { showing sharp contact; } \\
\text { G5 grades to G6 }\end{array}$ & $\begin{array}{l}\text { NNE of Sabugueiro, } \\
\text { intruded G4, showing } \\
\text { a sharp contact }\end{array}$ & $\begin{array}{l}\text { E of Cativelos; } \\
\text { intruded G5 and } \\
\text { G6, showing } \\
\text { sharp contacts }\end{array}$ \\
\hline \multicolumn{2}{|l|}{$\begin{array}{l}\text { Numbers and bodies' } \\
\text { orientation * }\end{array}$} & 1, NNW-SSE & $1 \mathrm{NE}-\mathrm{SW}$ & $2, \mathrm{E}-\mathrm{W}$ & $2, \mathrm{~N}-\mathrm{S}$ & 2, E-W & 8, E-W, NE-SW, N-S & 1, NW-SE & 1, NE-SW \\
\hline \multicolumn{2}{|l|}{ Deformation } & Undeformed & $\begin{array}{l}\text { Deformed } \mathrm{N} 70^{\circ} \mathrm{W} \text {, } \\
\text { subvertical }\end{array}$ & $\begin{array}{l}\text { Less deformed } \mathrm{N} 45^{\circ} \mathrm{W} \\
\text { to } \mathrm{N} 50^{\circ} \mathrm{W}\end{array}$ & $\begin{array}{l}\text { Even less deformed } \\
\mathrm{N} 50^{\circ} \mathrm{W} \text {, subvertical; } \\
\mathrm{N} 55^{\circ} \mathrm{W}, 75^{\circ} \mathrm{S}\end{array}$ & Undeformed & Undeformed & Undeformed & Undeformed \\
\hline \multicolumn{2}{|l|}{ Enclaves } & - & Metasedimentary & Metasedimentary & $\begin{array}{l}\text { Microgranular, } \\
\text { metasedimentary }\end{array}$ & $\begin{array}{l}\text { Microgranular, } \\
\text { metasedimentary }\end{array}$ & $\begin{array}{l}\text { Microgranular, } \\
\text { metasedimentary }\end{array}$ & Metasedimentary & $\begin{array}{l}\text { Microgranular, } \\
\text { metasedimentary }\end{array}$ \\
\hline \multicolumn{2}{|c|}{$\begin{array}{l}\text { Average dimensions (mm) } \\
\text { for phenocrysts }\end{array}$} & - & $10 \times 7$ & $7 \times 5$ up to $21 \times 5$ & $30 \times 30$ & $30 \times 20$ up to $60 \times 30$ & $15 \times 6$ up to $30 \times 20$ & $14 \times 8$ & $6 \times 3$ up to $14 \times 10$ \\
\hline \multicolumn{2}{|l|}{ Biotite $\%$} & 7.1 & 3.4 & 2.4 & 8.6 & 4.2 & 3.5 & 2.4 & 4.7 \\
\hline \multicolumn{2}{|l|}{$\begin{array}{l}\text { Muscovite \% } \\
\text { An of plagioclase }\end{array}$} & 0.0 & 11.4 & 11.6 & 4.6 & 9.7 & 12.6 & 9.1 & 5.1 \\
\hline \multirow{3}{*}{ Or of K-feldspar } & Phen. & $13-62$ & - & $0-9$ & $5-30$ & $18-29$ & $1-16$ & $10-2$ & - \\
\hline & Matrix & $7-41$ & $0-8$ & $0-6$ & $2-24$ & $1-16$ & $0-11$ & $1-6$ & $5-16$ \\
\hline & Phen. & - & 91-97 & - & $90-94$ & $90-100$ & $93-100$ & - & $87-100$ \\
\hline & Matrix & $75-100$ & $94-100$ & $93-100$ & $88-97$ & $87-100$ & $94-100$ & $95-100$ & $92-100$ \\
\hline \multirow{2}{*}{ wt.\% $\mathrm{BaO}$ of K-feldspar } & Phen. & - & $\leq 0.06-0.18$ & - & $\leq 0.06-0.29$ & $\leq 0.06-0.18$ & $\leq 0.06-0.08$ & & $0.06-0.21$ \\
\hline & Matrix & $\leq 0.06-0.51$ & $\leq 0.06-0.13$ & $\leq 0.06-0.17$ & $\leq 0.06-0.14$ & $\leq 0.06$ & $\leq 0.06$ & $\leq 0.06-0.09$ & $\leq 0.06$ \\
\hline
\end{tabular}

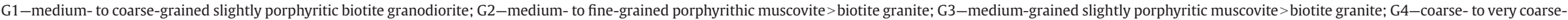

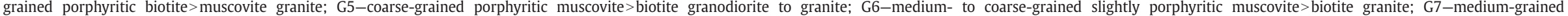

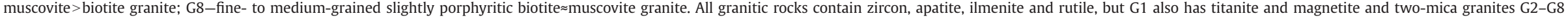
have monazite. G2 has garnet, G6 shows sillimanite and magmatic andalusite and G6 and G7 contain tourmaline. Phen.-phenocrysts. - they do not occur. *-of long axes of elliptical plutons. 
Table 2

Average whole-rock chemical analyses in wt.\%, trace elements and rare earths in ppm of granitic rocks from the Gouveia area, central Portugal

\begin{tabular}{|c|c|c|c|c|c|c|c|c|c|c|c|c|c|c|}
\hline & G1 & $\sigma$ & G2 & G3 & $\sigma$ & G4 & $\sigma$ & G5 & G6 & $\sigma$ & G7 & $\sigma$ & G8 & $\sigma$ \\
\hline$\overline{\mathrm{SiO}_{2}}$ & 69.20 & 1.13 & 74.39 & 72.80 & 0.75 & 71.72 & 1.96 & 71.14 & 73.54 & 0.42 & 73.71 & 0.39 & 72.79 & 0.37 \\
\hline $\mathrm{TiO}_{2}$ & 0.51 & 0.06 & 0.04 & 0.15 & 0.04 & 0.33 & 0.11 & 0.41 & 0.16 & 0.01 & 0.10 & 0.02 & 0.25 & 0.02 \\
\hline $\mathrm{Al}_{2} \mathrm{O}_{3}$ & 15.02 & 0.36 & 14.67 & 14.99 & 0.28 & 14.19 & 0.47 & 14.05 & 14.21 & 0.17 & 14.62 & 0.09 & 14.27 & 0.13 \\
\hline $\mathrm{Fe}_{2} \mathrm{O}_{3}$ & 1.10 & 0.14 & 0.18 & 0.25 & 0.18 & 0.40 & 0.09 & 0.40 & 0.35 & 0.09 & 0.40 & 0.14 & 0.20 & 0.11 \\
\hline $\mathrm{FeO}$ & 1.74 & 0.27 & 0.43 & 0.77 & 0.22 & 1.65 & 0.52 & 2.14 & 1.02 & 0.10 & 0.60 & 0.16 & 1.34 & 0.08 \\
\hline $\mathrm{MnO}$ & 0.05 & 0.01 & 0.03 & - & & 0.03 & 0.02 & 0.05 & 0.03 & - & 0.03 & - & 0.03 & - \\
\hline $\mathrm{MgO}$ & 1.20 & 0.17 & 0.11 & 0.26 & 0.09 & 0.47 & 0.16 & 0.56 & 0.25 & 0.04 & 0.18 & 0.04 & 0.35 & 0.03 \\
\hline $\mathrm{CaO}$ & 2.80 & 0.29 & 0.48 & 0.46 & 0.10 & 0.86 & 0.51 & 1.38 & 0.54 & 0.13 & 0.52 & 0.05 & 1.04 & 0.11 \\
\hline $\mathrm{Na}_{2} \mathrm{O}$ & 4.10 & 0.20 & 3.35 & 3.50 & 0.38 & 3.13 & 0.65 & 3.32 & 3.05 & 0.19 & 3.02 & 0.08 & 2.75 & 0.13 \\
\hline $\mathrm{K}_{2} \mathrm{O}$ & 2.55 & 0.20 & 4.20 & 4.32 & 0.40 & 5.19 & 0.36 & 5.02 & 4.79 & 0.23 & 4.65 & 0.24 & 5.17 & 0.22 \\
\hline $\mathrm{P}_{2} \mathrm{O}_{5}$ & 0.16 & 0.02 & 0.35 & 0.34 & 0.06 & 0.27 & 0.04 & 0.24 & 0.28 & 0.03 & 0.37 & 0.05 & 0.20 & 0.02 \\
\hline LOI & 1.27 & 0.28 & 1.48 & 1.68 & 0.22 & 1.39 & 0.26 & 1.25 & 1.39 & 0.22 & 1.38 & 0.27 & 1.24 & 0.07 \\
\hline Total & 99.70 & 0.15 & 99.71 & 99.52 & 0.11 & 99.63 & 0.13 & 99.96 & 99.61 & 0.13 & 99.58 & 0.11 & 99.63 & 0.11 \\
\hline $\mathrm{A} / \mathrm{CNK}$ & 1.03 & 0.04 & 1.34 & 1.33 & 0.06 & 1.16 & 0.11 & 1.06 & 1.27 & 0.06 & 1.33 & 0.01 & 1.19 & 0.03 \\
\hline C & 0.81 & & 4.58 & 4.53 & & 2.51 & & 1.22 & 3.70 & & 4.56 & & 2.74 & \\
\hline $\mathrm{F}$ & 523 & 154 & 668 & 1080 & 193 & 1290 & 235 & 1403 & 1790 & 286 & 861 & 35 & 1316 & 92 \\
\hline $\mathrm{Nb}$ & 4 & 1 & 5 & 6 & 2 & 12 & 2 & 20 & 18 & 1 & 13 & 1 & 15 & 1 \\
\hline $\mathrm{Zn}$ & 34 & 9 & 20 & 85 & 14 & 60 & 11 & 77 & 61 & 6 & 52 & 7 & 68 & 7 \\
\hline Sn & * & & 19 & 19 & 3 & 16 & 6 & 19 & 32 & 2 & 40 & 3 & 19 & 2 \\
\hline $\mathrm{Li}$ & 49 & 20 & 40 & 178 & 29 & 136 & 40 & 172 & 242 & 37 & 231 & 12 & 232 & 12 \\
\hline $\mathrm{Zr}$ & 112 & 11 & 12 & 57 & 14 & 139 & 44 & 184 & 79 & 8 & 36 & 11 & 119 & 11 \\
\hline $\mathrm{Cu}$ & 13 & 3 & 4 & 6 & 9 & 14 & 8 & 20 & 5 & 7 & $*$ & & 11 & 1 \\
\hline Y & 14 & 2 & 8 & 8 & 3 & 14 & 7 & 27 & 18 & 2 & 15 & 3 & 16 & 2 \\
\hline $\mathrm{Sr}$ & 296 & 22 & 40 & 45 & 16 & 89 & 25 & 87 & 54 & 8 & 56 & 10 & 118 & 5 \\
\hline $\mathrm{Pb}$ & 21 & 15 & 39 & 25 & 21 & 35 & 11 & 26 & 38 & 20 & 49 & 27 & 35 & 8 \\
\hline Ва & 475 & 21 & 162 & 173 & 98 & 357 & 135 & 368 & 192 & 21 & 137 & 38 & 413 & 53 \\
\hline $\mathrm{Rb}$ & 52 & 8 & 181 & 262 & 13 & 252 & 13 & 324 & 393 & 29 & 292 & 15 & 328 & 11 \\
\hline Th & 8 & 2 & $0.10^{\bullet}$ & $2.60^{\bullet}$ & & 15 & 5 & 26 & 12 & 2 & $2.10^{\bullet}$ & & 15 & 3 \\
\hline $\mathrm{U}$ & 2.59 & & 5.66 & 7.33 & & 6.97 & & 19.60 & 16.00 & & 6.43 & & 3.95 & \\
\hline La & 25.05 & & 1.10 & 9.10 & & 28.40 & & 36.00 & 19.45 & & 6.55 & & 34.56 & \\
\hline $\mathrm{Ce}$ & 51.45 & & 1.80 & 19.30 & & 59.25 & & 78.55 & 36.25 & & 13.70 & & 70.05 & \\
\hline $\mathrm{Pr}$ & 6.27 & & 0.22 & 2.47 & & 7.17 & & 9.56 & 4.41 & & 1.74 & & 8.27 & \\
\hline $\mathrm{Nd}$ & 22.90 & & 0.70 & 9.30 & & 26.35 & & 34.00 & 15.52 & & 6.35 & & 29.00 & \\
\hline $\mathrm{Sm}$ & 4.45 & & 0.20 & 2.80 & & 5.15 & & 7.35 & 3.58 & & 1.85 & & 5.65 & \\
\hline $\mathrm{Eu}$ & 1.06 & & 0.05 & 0.28 & & 0.79 & & 0.58 & 0.29 & & 0.39 & & 0.85 & \\
\hline Gd & 4.02 & & 0.20 & 2.59 & & 4.35 & & 6.35 & 3.18 & & 2.02 & & 4.56 & \\
\hline $\mathrm{Tb}$ & 0.60 & & 0.05 & 0.43 & & 0.68 & & 0.98 & 0.54 & & 0.40 & & 0.63 & \\
\hline Dy & 3.00 & & 0.27 & 1.80 & & 3.38 & & 5.16 & 2.72 & & 2.22 & & 2.84 & \\
\hline Ho & 0.59 & & 0.06 & 0.37 & & 0.62 & & 1.02 & 0.51 & & 0.37 & & 0.55 & \\
\hline $\mathrm{Er}$ & 1.56 & & 0.14 & 0.76 & & 1.58 & & 2.69 & 1.28 & & 0.83 & & 1.51 & \\
\hline $\mathrm{Tm}$ & 0.26 & & 0.045 & 0.11 & & 0.25 & & 0.39 & 0.20 & & 0.12 & & 0.23 & \\
\hline $\mathrm{Yb}$ & 1.72 & & 0.30 & 0.66 & & 1.76 & & 2.50 & 1.25 & & 0.70 & & 1.50 & \\
\hline $\mathrm{Lu}$ & 0.26 & & 0.045 & 0.09 & & 0.26 & & 0.40 & 0.18 & & 0.10 & & 0.19 & \\
\hline $\mathrm{N}$ & 9 & & 3 & 7 & & 6 & & 3 & 18 & & 7 & & 8 & \\
\hline
\end{tabular}

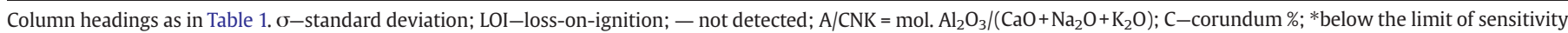

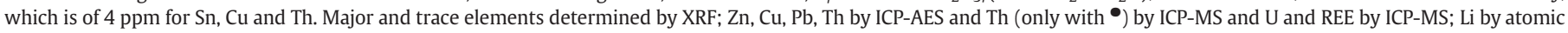
absorption; F by selective ion electrode; FeO by titration. $N$-number of analyses. REE contents of selected samples.

Euhedral garnet crystals in muscovite>biotite granite G2 have fractures filled by micas. Euhedral andalusite crystals are included in micas in muscovite>biotite granite G6. Needles of sillimanite occur as inclusions in muscovite, more rarely in feldspars and quartz, and locally in andalusite from G6. Schorl occurs in granites G6 and G7 as anhedral unzoned crystals containing inclusions of zircon, apatite and ilmenite. Schorl partially replaces micas.

Some alteration is evident, for example chloritization of biotite and the occurrence of secondary muscovite replacing feldspars, particularly plagioclase. It is most pronounced in granite G2. The dominant chlorite composition is chamosite.

\section{Analytical methods}

The major and trace element (Nb, Sn, Zr, Y, Sr, Ba, Rb and Th) abundances in the granitic rocks were determined by X-ray fluorescence (XRF) using the Tertian and Claisse (1982) method, with precisions better than $1 \%$ for major elements and $\mathrm{Rb}$, and about $\pm 4 \%$ for the other trace elements. $\mathrm{Zn}, \mathrm{Cu}$ and $\mathrm{Pb}$ were determined by ICP-AES with a precision of about $\pm 5 \%$. Li was analysed by atomic absorption with a precision of $\pm 2 \%$. All these determinations were carried out at INETI, S. Mamede de Infesta, Portugal.
The micas were separated with a magnetic separator and heavy liquids to determine their bulk trace elements. The purity was estimated to be $\sim 99.8 \%$ by petrographic examination. The main contaminants were inclusions of zircon, apatite and monazite. A very small amount of apatite and monazite can contain a very large amount of the REE. Therefore, REE of micas were not determined.

The $\mathrm{FeO}$ contents of the granitic rocks and biotites were determined by titration with a standardised potassium permanganate solution with a precision of $\pm 1 \%$. $F$ in the granitic rocks was measured by selective ion electrode analysis with a precision of about $\pm 2 \%$. Loss on ignition (LOI) for rocks was determined following the method of Lechler and Desilets (1987). Li contents of micas were determined by atomic absorption with a precision of $\pm 2 \%$. These determinations were carried out at the Department of Earth Sciences, University of Coimbra, Portugal. Trace elements in micas and U, REE in the granitic rocks and Th in a few of these rocks were determined by ICP-MS with a precision of $\pm 5 \%$ in SGS Laboratory, Toronto, Canada.

The major element compositions of the minerals were determined using the Modified Cambridge Geoscan Link System energy-dispersive system at Manchester University. Selected feldspars, micas and tourmalines were also analysed using a Cameca SX100 electron microprobe at this University, operating at $15 \mathrm{kV}$ accelerating voltage and 

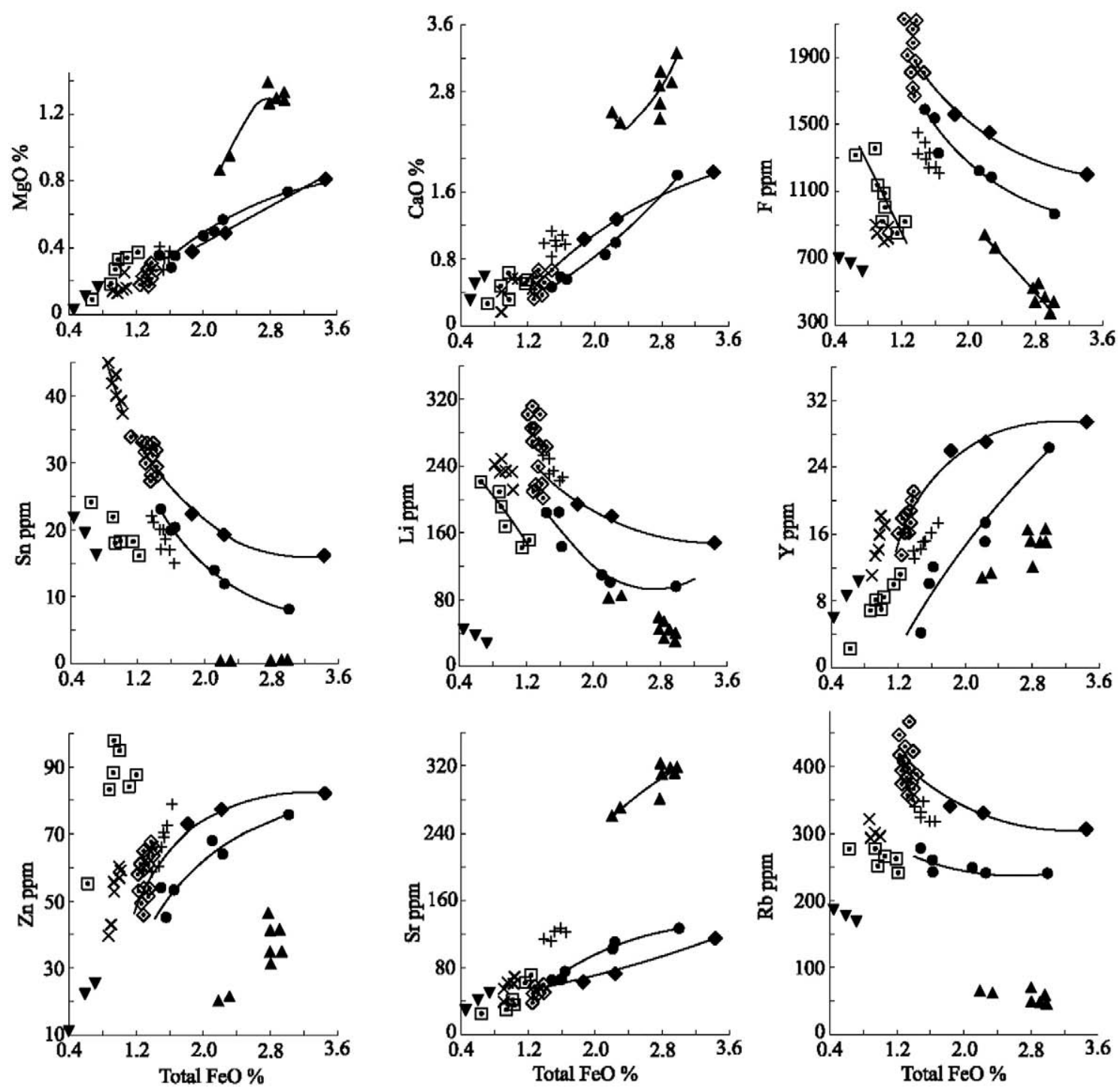

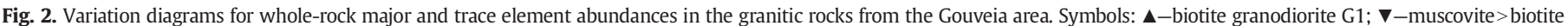

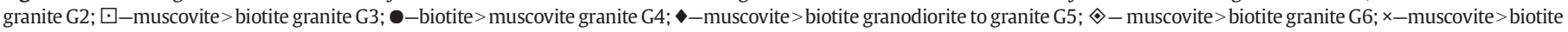
granite G7; +-biotite $\approx$ muscovite granite G8

$15 \mathrm{nA}$ beam current. Detection limits ( $3 \sigma$ above mean background) were 0.03 wt.\% oxide for most components, except $\mathrm{F}$ (0.1 wt.\%), $\mathrm{BaO}$ (0.06 wt.\%) and $\mathrm{Cl}$ (0.01 wt.\%), with counting times of $80 \mathrm{~s}$ for $\mathrm{F}, \mathrm{Cl}$ and $\mathrm{BaO}$.

Samples for $\mathrm{Sr}$ and $\mathrm{Nd}$ isotope analysis $(0.1000 \mathrm{~g})$ were digested with $\mathrm{HNO}_{3}+\mathrm{HF}$ in a Teflon-lined vessel. The elements were separated with ion-exchange resins, and the $\mathrm{Sr}$ and $\mathrm{Nd}$ isotope ratios were determined by thermal ionization mass spectrometry (TIMS) with a Finnigan Mat 262 at the University of Granada (Spain). All reagents were ultra clean. Normalization values were ${ }^{86} \mathrm{Sr} /{ }^{88} \mathrm{Sr}=0.1194$ and ${ }^{146} \mathrm{Nd} /{ }^{144} \mathrm{Nd}=0.7219$. Blanks were 0.6 and $0.09 \mathrm{ng}$ for $\mathrm{Sr}$ and $\mathrm{Nd}$. The external precision $(2 \sigma)$, estimated by analysing 10 replicates of the standard WS-E (Govindaraju et al., 1994), was better than $\pm 0.003 \%$ for ${ }^{87} \mathrm{Sr} /{ }^{86} \mathrm{Sr}$ and $\pm 0.0015 \%$ for ${ }^{143} \mathrm{Nd} /{ }^{144} \mathrm{Nd}$. The values obtained for the standards during isotopic measurements are ${ }^{87} \mathrm{Sr} /{ }^{86} \mathrm{Sr}=0.710252 \pm$ $0.000021(2 \sigma)$ for NBS $987(2 \sigma)$ and ${ }^{143} \mathrm{Nd} /{ }^{144} \mathrm{Nd}=0.511844 \pm 0.000010$ $(2 \sigma)$ for La Jolla. ${ }^{87} \mathrm{Rb} /{ }^{86} \mathrm{Sr}$ and ${ }^{147} \mathrm{Sm} /{ }^{144} \mathrm{Nd}$ ratios were determined by ICP-MS following the method developed by Montero and Bea (1998), with a precision better than $\pm 1.2 \%$ and $\pm 0.9 \%(2 \sigma)$ respectively.

Whole-rock oxygen isotopic compositions were measured, using a quartz standard, with a reproducibility of $\pm 0.2 \%$ at the Department of Earth Sciences, the University of Western Ontario, Canada.
Biotite granodiorite G1 and two-mica granites G3, G4, G5 and G8 were selected for zircon or monazite $\mathrm{U}-\mathrm{Th}-\mathrm{Pb}$ isotopic dating. About $500 \mathrm{~g}$ of each rock were crushed to $<250 \mu \mathrm{m}$ and the high density, weakly magnetic minerals $>20 \mu \mathrm{m}$ diameter extracted using high density liquids and a Frantz magnetic separator respectively. Final purification of the monazite and zircon separates was by hand picking.

Zircon and monazite were mounted separately in epoxy resin with grains of reference material; monazite-Thompson Mine WB.T.239 (radiogenic ${ }^{206} \mathrm{~Pb} /{ }^{238} \mathrm{U}=0.3152, \mathrm{U} \approx 2100 \mathrm{ppm}$ ), zircon-Temora $\left({ }^{206} \mathrm{~Pb}\right.$ / $\left.{ }^{238} \mathrm{U}=0.06683\right)$ and SL13 $(\mathrm{U}=238 \mathrm{ppm})$. The mounts were photographed in transmitted and reflected light, and the zircon internal textures imaged by cathodoluminescence (CL) using an Hitachi S2250 N SEM, prior to SHRIMP analysis. The monazite was imaged by backscattered electrons using a Cambridge Instruments Stereoscan 360 after SHRIMP analysis.

The U-Th-Pb isotopic analyses were carried out on SHRIMP ion microprobes at the Australian National University. Zircons from biotite granodiorite G1 were analysed on SHRIMP RG. Monazites from the two-mica granites were analysed on SHRIMP II. Analytical conditions were similar to those described by Williams et al. (1996). A 3-4 nA primary beam of $10 \mathrm{kV} \mathrm{O}_{2}^{-}$ions was focused to a probe $\sim 25 \mu \mathrm{m}$ diameter. Secondary ions were extracted at $10 \mathrm{kV}$ and mass analysed at a 

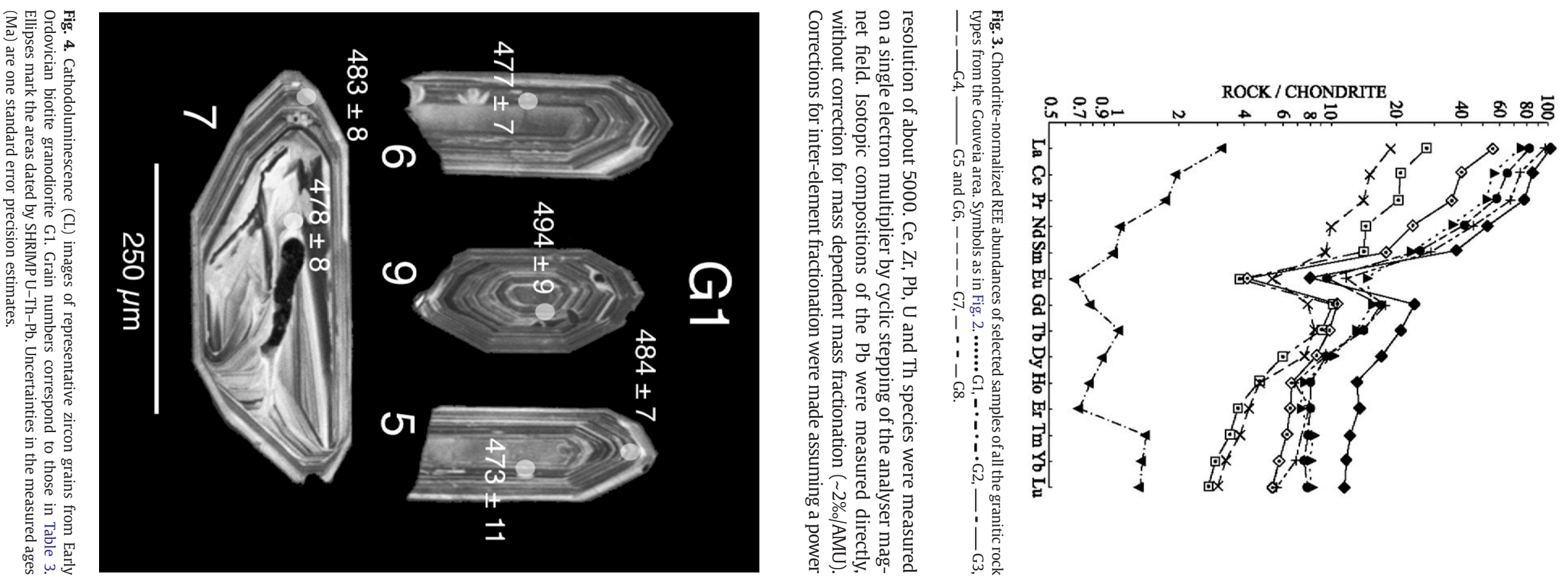

Table 3

U-Th-Pb analyses of zircon from granodiorite G1, Gouveia area, northern Portugal

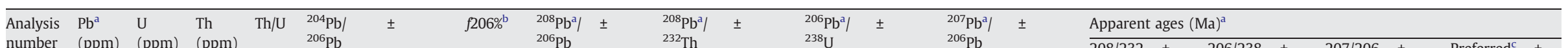

G1, GV60 (06-35) Biotite granodiorite

$\begin{array}{llllllll}1.1 & 21 & 280 & 93 & 0.33 & 1.29 \mathrm{E}-04 & 1.31 \mathrm{E}-04 & 0.23\end{array}$

$\begin{array}{lllllllll}2.1 & 27 & 353 & 133 & 0.38 & 7.26 \mathrm{E}-05 & 8.10 \mathrm{E}-05 & 0.13\end{array}$

$\begin{array}{rrrrrrrr}3.2 & 14 & 183 & 64 & 0.35 & 3.84 \mathrm{E}-04 & 2.80 \mathrm{E}-04 & 0.69 \\ 3.3 & 61 & 785 & 244 & 0.31 & 4.92 \mathrm{E}-05 & 4.55 \mathrm{E}-05 & 0.09\end{array}$

$\begin{array}{llllllll}4.1 & 52 & 508 & 733 & 1.44 & 3.34 \mathrm{E}-05 & 3.17 \mathrm{E}-05 & 0.06\end{array}$

$\begin{array}{llllllll}5.1 & 24 & 288 & 177 & 0.62 & 2.92 \mathrm{E}-05 & 3.78 \mathrm{E}-05 & 0.05 \\ 5.2 & 24 & 299 & 163 & 0.55 & 2.00 \mathrm{E}-05 & 2.00 \mathrm{E}-05 & 0.04\end{array}$

$\begin{array}{llllllll}6.1 & 27 & 336 & 192 & 0.57 & 3.12 \mathrm{E}-05 & 7.99 \mathrm{E}-05 & 0.06\end{array}$

$\begin{array}{llllllll}7.1 & 21 & 254 & 131 & 0.51 & 7.37 \mathrm{E}-05 & 9.25 \mathrm{E}-05 & 0.13\end{array}$

$\begin{array}{rrrrrrr}7.1 & 173 & 85 & 0.49 & 2.22 \mathrm{E}-04 & 1.99 \mathrm{E}-04 & 0.40\end{array}$

$\begin{array}{llllllll}9.1 & 21 & 254 & 115 & 0.45 & 2.00 \mathrm{E}-05 & 2.00 \mathrm{E}-05 & 0.04\end{array}$

$\begin{array}{llllllllll}0.0977 & 0.0061 & 0.02272 & 0.00149 & 0.07707 & 0.00121 & 0.05423 & 0.00224 & 454.1\end{array}$

$\begin{array}{lllllllll}0.1185 & 0.0042 & 0.02405 & 0.00103 & 0.07617 & 0.00074 & 0.05516 & 0.00151 & 480.4\end{array}$

$\begin{array}{llllllllll}0.1005 & 0.0118 & 0.02194 & 0.00262 & 0.07685 & 0.00146 & 0.05759 & 0.00458 & 438.7\end{array}$

$\begin{array}{llllllllll}0.0991 & 0.0030 & 0.02488 & 0.00081 & 0.07805 & 0.00082 & 0.05671 & 0.00099 & 496.7 \\ 0.447 & 0.0054 & 0.0243 & 0.00043 & 0.07900 & 0.00087 & 0.05678 & 0.00123 & 485.3\end{array}$

$\begin{array}{llllllllll}0.4437 & 0.0054 & 0.02430 & 0.00043 & 0.07900 & 0.00087 & 0.05678 & 0.00123 & 485.3 \\ 0.1859 & 0.0054 & 0.02352 & 0.00078 & 0.07789 & 0.00116 & 0.05551 & 0.00203 & 469.8\end{array}$

$\begin{array}{llllllllll}0.1859 & 0.0054 & 0.02352 & 0.00078 & 0.07789 & 0.00116 & 0.05551 & 0.00203 & 469.8 \\ 0.1722 & 0.0067 & 0.02407 & 0.0114 & 0.07631 & 0.00178 & 0.05806 & 0.00118 & 480.8\end{array}$

$\begin{array}{llllllllll}0.1722 & 0.0067 & 0.02407 & 0.00114 & 0.07631 & 0.00178 & 0.05806 & 0.00118 & 480.8\end{array}$

$\begin{array}{llllllllll}0.1788 & 0.0069 & 0.02407 & 0.00102 & 0.07675 & 0.00121 & 0.05694 & 0.00181 & 480.7 \\ 0.1599 & 0.0087 & 0.02418 & 0.00139 & 0.07775 & 0.00127 & 0.05679 & 0.00192 & 4829 \\ 0.1660 & 0.0107 & 0.02568 & 0.00175 & 0.07651 & 0.00138 & 0.05284 & 0.0039 & 512.6\end{array}$

$\begin{array}{llllllllll}0.1660 & 0.0107 & 0.02568 & 0.00175 & 0.07651 & 0.00138 & 0.05284 & 0.00390 & 512.6\end{array}$

$\begin{array}{lllllllllll}0.1552 & 0.0057 & 0.02468 & 0.00108 & 0.07929 & 0.00168 & 0.05754 & 0.00200 & 492.8\end{array}$ $\begin{array}{rl}29.5 & 47 \\ 20.3 & 473.6 \\ 52.0 & 477.3 \\ 16.0 & 48 \\ 8.4 & 490 . \\ 15.4 & 483.5 \\ 22.6 & 474.1 \\ 20.2 & 476.7 \\ 27.5 & 48 \\ 34.4 & 47 \\ 21.3 & 49 \\ 19.0 & 493 . \\ \end{array}$

\section{6}

$7.2 \quad 380.4$ $95.6-4801$

Corrected for common $\mathrm{Pb}$ of a composition calculated from the Cumming and Richards (1975) growth curve. Correction used ${ }^{204} \mathrm{~Pb}$.

Preferred age estimate, based on ${ }^{206} \mathrm{~Pb} /{ }^{238} \mathrm{U}$ corrected for common $\mathrm{Pb}$ using ${ }^{207} \mathrm{~Pb} /{ }^{206} \mathrm{~Pb}$, assuming concordance. 


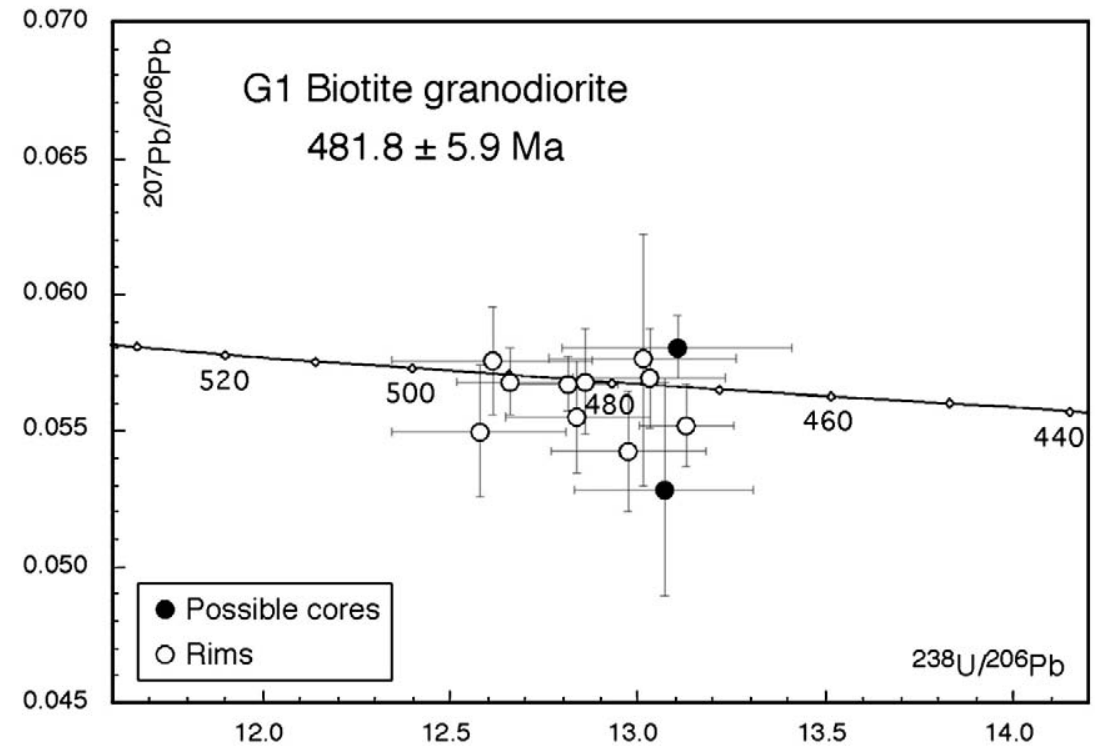

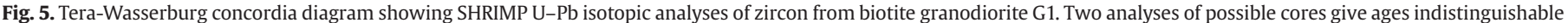
from those measured on zircon with simple, euhedral, oscillatory growth zoning. Analytical uncertainties are one standard error precision estimates.

law relationship between $\mathrm{Pb} / \mathrm{U}$ and $\mathrm{UO} / \mathrm{U}$ or $\mathrm{Pb} / \mathrm{Th}$ and $\mathrm{ThO} / \mathrm{Th}$ (ClaouéLong et al., 1995).

Common $\mathrm{Pb}$ corrections to the monazite analyses were small, so the common $\mathrm{Pb}$ was assumed to be surface contamination of Broken Hill galena composition. Corrections were made assuming $\mathrm{Pb}-\mathrm{U}$ concordance. The monazite ${ }^{206} \mathrm{~Pb} /{ }^{238} \mathrm{U}$ measurements were also corrected for the presence of initial ${ }^{230} \mathrm{Th}$ (Schärer, 1984), assuming $\mathrm{Th} / \mathrm{U}=4$ in the melt phase of the magmas. Common Pb corrections to the zircon analyses were larger, so the common $\mathrm{Pb}$ in each grain was assumed to have a composition consistent with the age of the grain (Cumming and Richards, 1975). Common Pb corrections were made using ${ }^{204} \mathrm{~Pb}$.

For comparative purposes, the monazite ages were calculated by two independent methods. The ${ }^{206} \mathrm{~Pb} /{ }^{238} \mathrm{U}$ ages were calculated using a calibration based on $\mathrm{UO}^{+} / \mathrm{U}^{+}$and ${ }^{206} \mathrm{~Pb}^{+} /{ }^{238} \mathrm{U}^{+}$. The ${ }^{208} \mathrm{~Pb} /{ }^{232} \mathrm{Th}$ ages were calculated using a calibration based on $\mathrm{ThO}^{+} / \mathrm{Th}^{+}$and ${ }^{208} \mathrm{~Pb}^{+} /$

${ }^{232} \mathrm{Th}^{+}$. The ages calculated by the two methods were in close agreement. All ages were calculated using the decay constants recommended by the IUGS Subcommission on Geochronology (Steiger and Jäger, 1977).

The uncertainties listed in the data tables and plotted in the Concordia diagrams are $1 \sigma$ analytical precision estimates. The uncertainties in the calculated mean ages for each sample are $95 \%$ confidence limits, i.e. $t$ sigma, where $t$ is the Student's $t$ multiplier, and include the uncertainties in the inter-element calibrations $(0.37 \%$ for monazite $\mathrm{Pb} / \mathrm{U}, 0.30 \%$ for monazite $\mathrm{Pb} / \mathrm{Th}$ and $0.40 \%$ for zircon $\mathrm{Pb} / \mathrm{U}$ ).

\section{Whole-rock geochemistry}

The major, trace and rare earth element contents of granitic rocks from the Gouveia area are listed in Table 2. The granitic rocks are all peraluminous, with average molecular $\mathrm{A} / \mathrm{CNK}$ ratios $\left(\mathrm{Al}_{2} \mathrm{O}_{3} /(\mathrm{CaO}+\right.$ $\left.\mathrm{Na}_{2} \mathrm{O}+\mathrm{K}_{2} \mathrm{O}\right)$ ) of 1.03 to 1.34 . The average normative corundum content is $0.81 \%$ in biotite granodiorite $\mathrm{G} 1$, and ranges between 1.22 and $4.58 \%$ in the two-mica granites.

Total $\mathrm{FeO}$ has been chosen as a differentiation index for the variation diagrams because it shows more variability in the granitic rocks than $\mathrm{SiO}_{2}$. The variation diagrams for selected major and trace elements in the granitic rocks show mainly subparallel curvilinear trends (Fig. 2). However, the muscovite> biotite granodiorite to granite G5 and granite G6 together define a single curvilinear variation trend in each diagram.
The chondrite-normalized REE patterns of all granitic rocks (Fig. 3) show enrichments in LREE relative to HREE $\left(\mathrm{La}_{N} / \mathrm{Lu}_{N}\right)=2-18$. Muscovite > biotite granite G2 is the lowest in $\Sigma$ REE and has a very unusual pattern attributed to some alteration effects. Muscovite > biotite granodiorite to granite G5 is the highest in $\mathrm{R}$ REE. The REE patterns of G5 and G6 are subparallel and the REE concentrations decrease from the former to the latter. However, most of the REE patterns cross-cut each other in LREE and HREE.

\section{Isotopic data}

\subsection{SHRIMP $U-T h-P b$ analyses of zircon and monazite}

The zircon grains from biotite granodiorite G1 are mostly large, clear, weakly coloured and sharply euhedral to slightly rounded. Cathodoluminescence imaging shows that most have relatively simple euhedral oscillatory zoning consistent with a single generation of zircon growth (Fig. 4). Very few grains have structurally discordant cores. Twelve $\mathrm{U}-\mathrm{Th}-\mathrm{Pb}$ isotopic analyses of 9 grains are listed in Table 3 and plotted on a Concordia diagram in Fig. 5. All analyses, even of possible cores (e.g. 7.2, Table 3), are concordant within analytical uncertainty at $\sim 480 \mathrm{Ma}$. All analysed grains have the same $\left.{ }^{206} \mathrm{~Pb} *\right|^{238} \mathrm{U}$ within uncertainty, equivalent to a weighted mean age of $481.8 \pm 5.9 \mathrm{Ma}$, which we interpret as the crystallization age of the granodiorite (Early Ordovician)

The monazite grains from the dated two-mica granites (G3, G4, G5 and G8) are honey yellow, euhedral, equant to slightly elongated and $80-250 \mu \mathrm{m}$ diameter. BSE images of the analysed grains from granites G4 and G8 show relatively simple concentric zoning, but in the grains from $\mathrm{G} 5$ that zoning is, in many cases, modified by patchy recrystallization (Fig. 6). Simple zoning is rare in the monazite from G3; most grains either have no obvious zoning or have a mosaic texture, and recrystallization, particularly around the margins of the grains, is common (Fig. 6).

$\mathrm{U}-\mathrm{Th}-\mathrm{Pb}$ isotopic analyses of 10 grains from each sample are listed in Table 4 and plotted on Pb-U-Th concordia diagrams in Fig. 7A-D. All the isotopic analyses are concordant, or very nearly so, within analytical uncertainty. Although the ${ }^{206} \mathrm{~Pb} /{ }^{238} \mathrm{U}$ ages are generally the more precise, ${ }^{208} \mathrm{~Pb} /{ }^{232} \mathrm{Th}$ is preferred for estimating the crystallization ages because it is unaffected by the presence of initial ${ }^{230} \mathrm{Th}$. Three of the grains from G3 (1, 3 and 9, Table 4) have significantly higher 


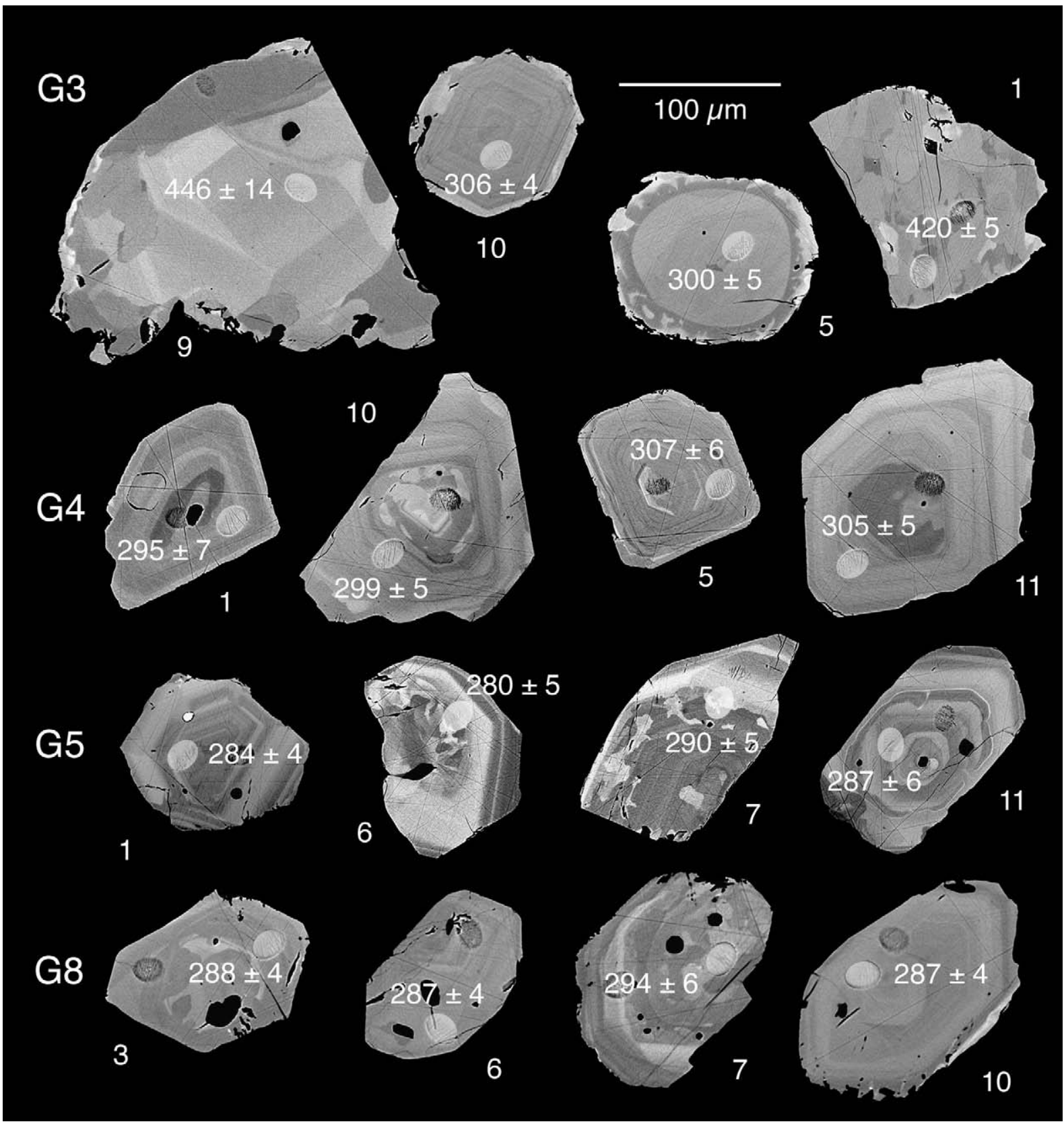



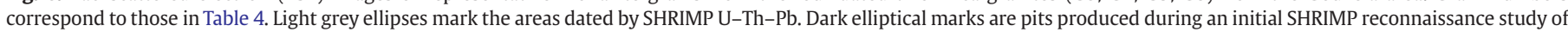
the grains. Uncertainties in the measured ages (Ma) are one standard error precision estimates.

apparent ages than the others ( $420, \sim 320$ and $\sim 446$ Ma respectively), suggesting either the presence of inheritance or, much less likely, major, uniform isotopic resetting of all the younger crystals. The 7 young grains have the same ${ }^{208} \mathrm{~Pb}^{*} /{ }^{232} \mathrm{Th}$ and ${ }^{206} \mathrm{~Pb}^{*} /{ }^{238} \mathrm{U}$ ages within analytical uncertainty, yielding a weighted mean ${ }^{208} \mathrm{~Pb} * / 232 \mathrm{Th}$ age of $303.8 \pm 3.2 \mathrm{Ma}$ (Fig. 7A). One grain from G4 (7) is slightly older than the rest. The remaining 9 grains have the same ${ }^{208} \mathrm{~Pb}^{*} /{ }^{232} \mathrm{Th}$ and ${ }^{206} \mathrm{~Pb} * /$ ${ }^{238} \mathrm{U}$ ages within analytical uncertainty, yielding a weighted mean ${ }^{208} \mathrm{~Pb}^{*}{ }^{232} \mathrm{Th}$ age of $301.4 \pm 2.6 \mathrm{Ma}$ (Fig. 7B). One grain from G5 (8) has a slightly lower ${ }^{208} \mathrm{~Pb}^{*} /{ }^{232} \mathrm{Th}$ and $\left.{ }^{206} \mathrm{~Pb}^{*}\right|^{238} \mathrm{U}$ than the rest. The remaining 9 grains have the same ${ }^{208} \mathrm{~Pb} * / 232 \mathrm{Th}$ and ${ }^{206} \mathrm{~Pb}^{*} /{ }^{238} \mathrm{U}$ ages within analytical uncertainty, yielding a weighted mean ${ }^{208} \mathrm{~Pb} * 2{ }^{232} \mathrm{Th}$ age of $288.6 \pm 2.5 \mathrm{Ma}$ (Fig. 7C). Similarly with G8, one grain (1) has a slightly lower ${ }^{208} \mathrm{~Pb} * / 232 \mathrm{Th}$ than the rest. The remaining 9 grains have the same ${ }^{208} \mathrm{~Pb}^{*} /{ }^{232} \mathrm{Th}$ and ${ }^{206} \mathrm{~Pb}^{*} /{ }^{238} \mathrm{U}$ ages within analytical uncer- tainty, yielding a weighted mean ${ }^{208} \mathrm{~Pb} * / 232 \mathrm{Th}$ age of $288.7 \pm 2.6 \mathrm{Ma}$ (Fig. 7D). The monazite in each granite is considered to be an igneous mineral, so the monazite ages are considered to record granite crystallization. The four granites are Variscan, but G5 and G8 are significantly younger than G3 and G4 (Table 5). The rare older monazite grains in granite $\mathrm{G} 3$ are considered to be inherited.

\section{2. $\mathrm{Rb}-\mathrm{Sr}, \mathrm{Sm}-\mathrm{Nd}$ and oxygen whole-rock analyses}

$\mathrm{Rb}-\mathrm{Sr}$ whole-rock isotopic analyses of biotite granodiorite $\mathrm{G} 1$ and two-mica granites G3-G8, and Sm-Nd isotopic analyses of G1, are listed in Table 6. Whole-rock oxygen isotopic compositions $\left(\delta^{18} \mathrm{O}\right)$ are listed in Table 7.

The six whole-rock $\mathrm{Rb}-\mathrm{Sr}$ analyses of granites $\mathrm{G} 5$ and G6 lie within analytical uncertainty on an isochron (Fig. 8) which yields an age 
Table 4

$\mathrm{U}-\mathrm{Th}-\mathrm{Pb}$ analyses of monazite from granitic rocks from the Gouveia area, northern Portugal

\begin{tabular}{|c|c|c|c|c|c|c|c|c|c|c|c|c|c|c|c|c|c|}
\hline \multirow{2}{*}{$\begin{array}{l}\text { Analysis } \\
\text { number }\end{array}$} & \multirow{2}{*}{$\begin{array}{l}\mathrm{Pb}^{\mathrm{b}} \\
(\mathrm{ppm})\end{array}$} & \multirow{2}{*}{$\begin{array}{l}\text { U } \\
(\mathrm{ppm})\end{array}$} & \multirow{2}{*}{$\begin{array}{l}\text { Th } \\
\text { (ppm) }\end{array}$} & \multirow[t]{2}{*}{$\mathrm{Th} / \mathrm{U}$} & \multirow[t]{2}{*}{$f 206 \%^{\mathrm{c}}$} & \multirow{2}{*}{$\begin{array}{l}{ }^{207} \mathrm{~Pb}^{\mathrm{a}} / \\
{ }^{206} \mathrm{~Pb}\end{array}$} & \multirow[t]{2}{*}{ \pm} & \multirow{2}{*}{$\begin{array}{l}{ }^{208} \mathrm{~Pb}^{\mathrm{b}} / \\
{ }^{206} \mathrm{~Pb}\end{array}$} & \multirow[t]{2}{*}{ \pm} & \multirow{2}{*}{$\begin{array}{l}{ }^{208} \mathrm{~Pb}^{\mathrm{b}} / \\
{ }^{232} \mathrm{Th}\end{array}$} & \multirow[t]{2}{*}{ \pm} & \multirow{2}{*}{$\begin{array}{l}{ }^{206} \mathrm{~Pb}^{\mathrm{b}} / \\
{ }^{238} \mathrm{U}\end{array}$} & \multirow[t]{2}{*}{ \pm} & \multicolumn{4}{|c|}{ Apparent ages $(\mathrm{Ma})^{\mathrm{b}}$} \\
\hline & & & & & & & & & & & & & & $208 / 232$ & \pm & $206 / 238$ & \pm \\
\hline \multicolumn{18}{|c|}{ G3, GV11 (06-33) Muscovite > biotite granite } \\
\hline 1 & 1148 & 8723 & 33,996 & 3.9 & 0.12 & 0.0562 & 0.0005 & 1.23 & 0.01 & 0.02102 & 0.00025 & 0.06680 & 0.00054 & 420.4 & 5.0 & 416.8 & 3.3 \\
\hline 2 & 568 & 3290 & 32,526 & 9.9 & 0.08 & 0.0531 & 0.0012 & 3.10 & 0.03 & 0.01505 & 0.00025 & 0.04799 & 0.00060 & 302.0 & 5.0 & 302.2 & 3.7 \\
\hline 3 & 733 & 6943 & 29,598 & 4.3 & 0.08 & 0.0536 & 0.0006 & 1.31 & 0.01 & 0.01592 & 0.00020 & 0.05163 & 0.00042 & 319.2 & 4.0 & 324.5 & 2.6 \\
\hline 4 & 753 & 7678 & 32,614 & 4.2 & 0.16 & 0.0538 & 0.0006 & 1.34 & 0.01 & 0.01494 & 0.00018 & 0.04751 & 0.00036 & 299.8 & 3.6 & 299.2 & 2.2 \\
\hline 5 & 731 & 7710 & 30,774 & 4.0 & 0.16 & 0.0538 & 0.0007 & 1.25 & 0.02 & 0.01494 & 0.00024 & 0.04770 & 0.00037 & 299.7 & 4.7 & 300.4 & 2.3 \\
\hline 6 & 577 & 5168 & 27,254 & 5.3 & 0.07 & 0.0529 & 0.0006 & 1.64 & 0.02 & 0.01490 & 0.00021 & 0.04798 & 0.00040 & 299.0 & 4.2 & 302.1 & 2.5 \\
\hline 7 & 693 & 7609 & 27,126 & 3.6 & 0.02 & 0.0525 & 0.0007 & 1.11 & 0.01 & 0.01518 & 0.00027 & 0.04879 & 0.00050 & 304.6 & 5.3 & 307.1 & 3.1 \\
\hline 9 & 1006 & 883 & 48,931 & 55.4 & 0.11 & 0.0571 & 0.0019 & 16.98 & 0.14 & 0.02231 & 0.00069 & 0.07281 & 0.00183 & 446.0 & 13.6 & 453.1 & 11.0 \\
\hline 10 & 709 & 5378 & 35,630 & 6.6 & 0.01 & 0.0525 & 0.0006 & 2.08 & 0.02 & 0.01527 & 0.00020 & 0.04875 & 0.00043 & 306.3 & 3.9 & 306.8 & 2.7 \\
\hline 11 & 629 & 6794 & 25,405 & 3.7 & 0.04 & 0.0527 & 0.0010 & 1.16 & 0.01 & 0.01504 & 0.00021 & 0.04847 & 0.00042 & 301.7 & 4.1 & 305.1 & 2.6 \\
\hline \multicolumn{18}{|c|}{ G4, GV55 (06-34) Biotite>muscovite granite } \\
\hline 1 & 994 & 2056 & 71,007 & 34.5 & 0.23 & 0.0545 & 0.0012 & 10.70 & 0.16 & 0.01470 & 0.00033 & 0.04745 & 0.00073 & 295.0 & 6.5 & 298.8 & 4.5 \\
\hline 2 & 808 & 736 & 60,341 & 82.0 & 0.24 & 0.0546 & 0.0026 & 26.01 & 0.42 & 0.01485 & 0.00040 & 0.04680 & 0.00090 & 297.9 & 7.9 & 294.9 & 5.6 \\
\hline 3 & 819 & 1505 & 58,042 & 38.6 & 0.11 & 0.0534 & 0.0024 & 11.89 & 0.15 & 0.01495 & 0.00030 & 0.04851 & 0.00069 & 300.0 & 5.9 & 305.4 & 4.3 \\
\hline 4 & 841 & 2140 & 57,206 & 26.7 & 0.24 & 0.0547 & 0.0019 & 8.49 & 0.06 & 0.01508 & 0.00023 & 0.04750 & 0.00057 & 302.6 & 4.7 & 299.2 & 3.5 \\
\hline 5 & 683 & 1792 & 45,472 & 25.4 & 0.17 & 0.0540 & 0.0010 & 7.92 & 0.09 & 0.01530 & 0.00029 & 0.04903 & 0.00066 & 307.0 & 5.8 & 308.6 & 4.0 \\
\hline 6 & 788 & 1621 & 54,825 & 33.8 & 0.07 & 0.0531 & 0.0011 & 10.47 & 0.09 & 0.01506 & 0.00024 & 0.04866 & 0.00057 & 302.2 & 4.7 & 306.3 & 3.5 \\
\hline 7 & 790 & 883 & 58,192 & 65.9 & 0.07 & 0.0530 & 0.0020 & 19.89 & 0.25 & 0.01487 & 0.00040 & 0.04924 & 0.00104 & 298.3 & 7.9 & 309.9 & 6.4 \\
\hline 9 & 754 & 1621 & 52,687 & 32.5 & 0.07 & 0.0531 & 0.0018 & 9.92 & 0.13 & 0.01492 & 0.00037 & 0.04887 & 0.00091 & 299.3 & 7.4 & 307.6 & 5.6 \\
\hline 10 & 731 & 1514 & 51,355 & 33.9 & 0.07 & 0.0531 & 0.0016 & 10.45 & 0.09 & 0.01492 & 0.00025 & 0.04841 & 0.00064 & 299.2 & 5.1 & 304.8 & 3.9 \\
\hline 11 & 841 & 2547 & 55,267 & 21.7 & 0.00 & 0.0521 & 0.0014 & 6.81 & 0.06 & 0.01522 & 0.00022 & 0.04850 & 0.00049 & 305.3 & 4.5 & 305.3 & 3.0 \\
\hline G5, GV47 & $06-36) N$ & uscovite $>$ & biotite gra & hodiorit & & & & & & & & & & & & & \\
\hline 1 & 1115 & 4664 & 75,099 & 16.1 & 0.10 & 0.05 & 0.0011 & 5.00 & 0.04 & & & & & 284.2 & 4.1 & 287.7 & 3.1 \\
\hline 3 & 715 & 1325 & 53,035 & 40.0 & 0.44 & 0.0561 & 0.0014 & 12.45 & 0.17 & 0.01434 & 0.00033 & 0.04609 & 0.00081 & 287.7 & 6.7 & 290.5 & 5.0 \\
\hline 4 & 934 & 2700 & 65,438 & 24.2 & 0.00 & 0.0519 & 0.0013 & 7.54 & 0.06 & 0.01446 & 0.00020 & 0.04648 & 0.00048 & 290.1 & 4.1 & 292.9 & 2.9 \\
\hline 5 & 676 & 1151 & 50,088 & 43.5 & 0.24 & 0.0543 & 0.0016 & 13.52 & 0.17 & 0.01445 & 0.00032 & 0.04651 & 0.00074 & 289.9 & 6.4 & 293.1 & 4.6 \\
\hline 6 & 727 & 1678 & 54,227 & 32.3 & 0.30 & 0.0549 & 0.0011 & 9.84 & 0.10 & 0.01397 & 0.00024 & 0.04592 & 0.00057 & 280.4 & 4.8 & 289.4 & 3.5 \\
\hline 7 & 866 & 3466 & 57,529 & 16.6 & 0.09 & 0.0530 & 0.0008 & 5.17 & 0.06 & 0.01444 & 0.00022 & 0.04633 & 0.00045 & 289.7 & 4.5 & 292.0 & 2.8 \\
\hline 8 & 687 & 1119 & 52,909 & 47.3 & 0.23 & 0.0542 & 0.0013 & 14.53 & 0.18 & 0.01397 & 0.00031 & 0.04544 & 0.00074 & 280.4 & 6.3 & 286.5 & 4.6 \\
\hline 9 & 838 & 1975 & 60,700 & 30.7 & 0.05 & 0.0525 & 0.0011 & 9.65 & 0.08 & 0.01436 & 0.00021 & 0.04576 & 0.00048 & 288.2 & 4.2 & 288.5 & 2.9 \\
\hline 10 & 830 & 3031 & 56,808 & 18.7 & 0.00 & 0.0520 & 0.0014 & 5.79 & 0.05 & 0.01427 & 0.00020 & 0.04620 & 0.00043 & 286.4 & 4.0 & 291.2 & 2.6 \\
\hline 11 & 827 & 1310 & 62,349 & 47.59 & 0.00 & 0.0517 & 0.0013 & 14.95 & 0.14 & 0.01429 & 0.00029 & 0.04547 & 0.00070 & 286.7 & 5.7 & 286.7 & 4.3 \\
\hline oo, 0 vo & -37) $T$ & 更 & & & & & & & & & & & & & & & \\
\hline 1 & 631 & 1443 & 46,991 & 32.6 & 0.22 & 0.0340 & 0.0013 & 10.14 & 0.15 & 0.01404 & 0.00032 & 0.04509 & 0.00074 & 281.8 & 6.4 & 284.3 & 4.6 \\
\hline 2 & 1257 & 13,060 & 58,962 & 4.5 & 0.00 & 0.0520 & 0.0004 & 1.42 & 0.02 & 0.01417 & 0.00022 & 0.04503 & 0.00038 & 284.4 & 4.4 & 284.0 & 2.3 \\
\hline 3 & 783 & 7344 & 38,542 & 5.2 & 0.10 & 0.0529 & 0.0006 & 1.64 & 0.02 & 0.01433 & 0.00019 & 0.04576 & 0.00039 & 287.6 & 3.8 & 288.5 & 2.4 \\
\hline 4 & 1038 & 8020 & 57,230 & 7.1 & 0.00 & 0.0519 & 0.0006 & 2.21 & 0.02 & 0.01422 & 0.00018 & 0.04581 & 0.00041 & 285.4 & 3.5 & 288.8 & 2.5 \\
\hline 5 & 860 & 5818 & 49,549 & 8.5 & 0.07 & 0.0526 & 0.0006 & 2.68 & 0.02 & 0.01441 & 0.00020 & 0.04575 & 0.00046 & 289.2 & 4.0 & 288.4 & 2.9 \\
\hline 6 & 979 & 4646 & 63,668 & 13.7 & 0.08 & 0.0527 & 0.0010 & 4.30 & 0.03 & 0.01427 & 0.00019 & 0.04547 & 0.00045 & 286.5 & 3.8 & 286.6 & 2.8 \\
\hline 7 & 850 & 2196 & 59,665 & 27.2 & 0.14 & 0.0533 & 0.0010 & 8.61 & 0.10 & 0.01465 & 0.00031 & 0.04623 & 0.00073 & 294.0 & 6.2 & 291.3 & 4.5 \\
\hline 9 & 1063 & 7344 & 60,684 & 8.3 & 0.04 & 0.0523 & 0.0008 & 2.58 & 0.03 & 0.01439 & 0.00019 & 0.04609 & 0.00030 & 288.7 & 3.7 & 290.5 & 1.9 \\
\hline 10 & 957 & 5019 & 60,471 & 12.0 & 0.15 & 0.0534 & 0.0007 & 3.79 & 0.03 & 0.01431 & 0.00020 & 0.04545 & 0.00042 & 287.2 & 3.9 & 286.6 & 2.6 \\
\hline 12 & 588 & 1087 & 44,430 & 40.9 & 0.11 & 0.0530 & 0.0015 & 12.85 & 0.20 & 0.01411 & 0.00036 & 0.04488 & 0.00083 & 283.2 & 7.2 & 283.0 & 5.1 \\
\hline
\end{tabular}

a Not corrected for common $\mathrm{Pb}$.

b Corrected for common $\mathrm{Pb}$ of Broken Hill galena composition using ${ }^{207} \mathrm{~Pb} /{ }^{206} \mathrm{~Pb}$ and assuming concordance.

c Percentage of total ${ }^{206} \mathrm{~Pb}$ that is common ${ }^{206} \mathrm{~Pb}$.

of $294 \pm 3 \mathrm{Ma}\left(\left({ }^{87} \mathrm{Sr} /{ }^{86} \mathrm{Sr}\right)_{294}=0.7077\right)$, indistinguishable from the monazite age of G5 (288.6 $\pm 2.5 \mathrm{Ma})$.

Biotite granodiorite $\mathrm{G} 1$ has $\left({ }^{87} \mathrm{Sr} /{ }^{86} \mathrm{Sr}\right)_{482}=0.7036 \pm 0.0001, \varepsilon \mathrm{Nd}_{482}=$ +2.5 and $\delta^{18} \mathrm{O}=8.9 \pm 0.1 \%$. The initial ${ }^{87} \mathrm{Sr} /{ }^{86} \mathrm{Sr}$ ratios for the two-mica granites are significantly higher: G3: $0.7174 \pm 0.0060$, G4: $0.7090 \pm$ 0.0001, G5: 0.7076 \pm 0.0003 , G6: 0.7078 \pm 0.0010, G7: $0.7129 \pm 0.0036$ and G8: $0.7115 \pm 0.0011$ (Table 6). The $\delta^{18} \mathrm{O}$ values for the two-mica granites from the Gouveia area are also very high: G2: $12.3 \%$, G3: 13.4\%。, G4: $12.1 \%$, G5: $10.7 \%$, G6: $11.2 \%$, G7: $12.8 \%$ ond G8: $11.5 \%$ (Table 7). The mean $\delta^{18} \mathrm{O}$ value rises from G5 to G6 (Fig. 9).

\section{Mineral chemistry}

\subsection{Feldspars}

The compositions of plagioclase and microcline from the eight granitic rocks are listed in Table 1. Neither feldspar contains significant $\mathrm{P}_{2} \mathrm{O}_{5}$. The anorthite content decreases from phenocryst to matrix plagioclase. The Ba content of matrix microcline is lower than that of phenocryst microcline, suggesting that the phenocrysts were precipitated from the melt-phase of the magmas (e.g. Long and Luth, 1986). Anorthite content of phenocryst and matrix plagioclase decrease from G5 to G6. The orthoclase content tends to increase and the Ba content decreases in both the phenocryst and matrix microcline from G5 to G6.

\subsection{Micas}

The average major and trace element contents of the analysed biotites and muscovites are given in Tables 8 and 9, respectively. Biotite granodiorite $\mathrm{G} 1$ contains biotite with $\mathrm{Mg} /\left(\mathrm{Mg}+\mathrm{Fe}^{2+}+\mathrm{Fe}^{3+}\right)=$ 0.52 , whereas the two-mica granites have biotites with $\mathrm{Mg} /\left(\mathrm{Mg}+\mathrm{Fe}^{2+}+\right.$ $\mathrm{Fe}^{3+}$ ) of 0.16-0.29 (Rieder et al., 1999). The biotites have compositions similar to those found in biotites from calc-alkaline rocks and aluminium-potassic rock series, respectively (Nachit et al., 1985).

Trace element variations in the biotites define subparallel trends for the plutons (Fig. 10A-C), except the biotites from G5 and G6, which lie on a single trend. 

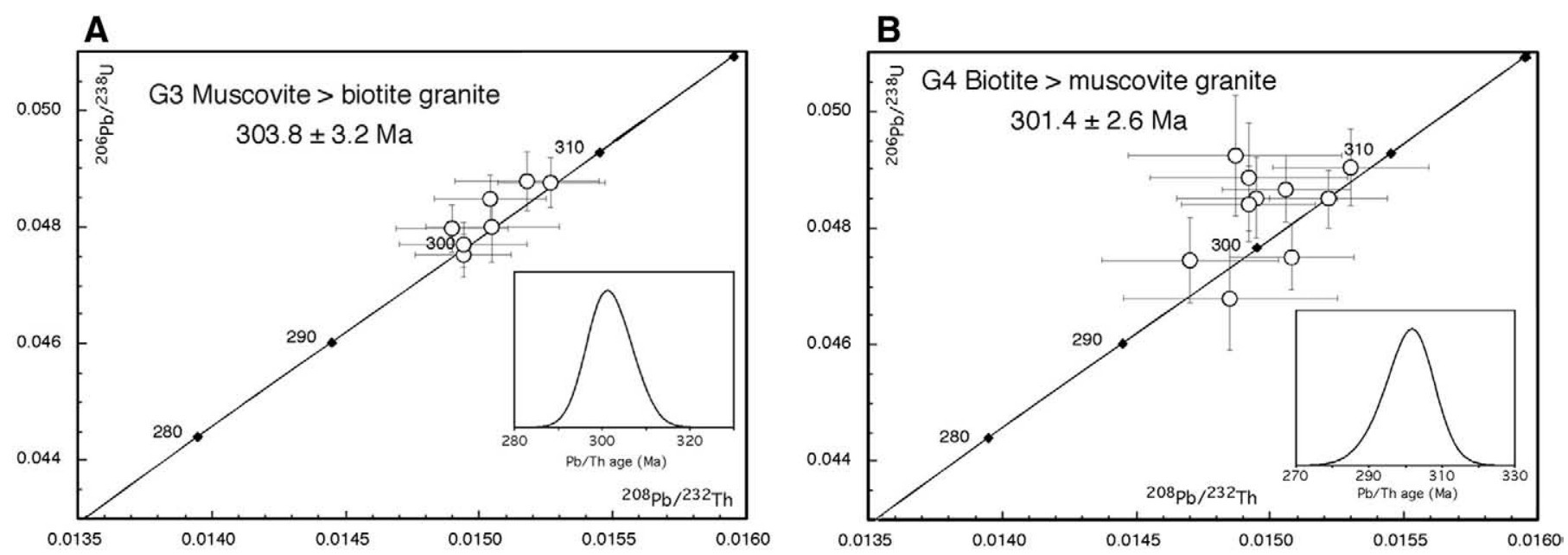

C
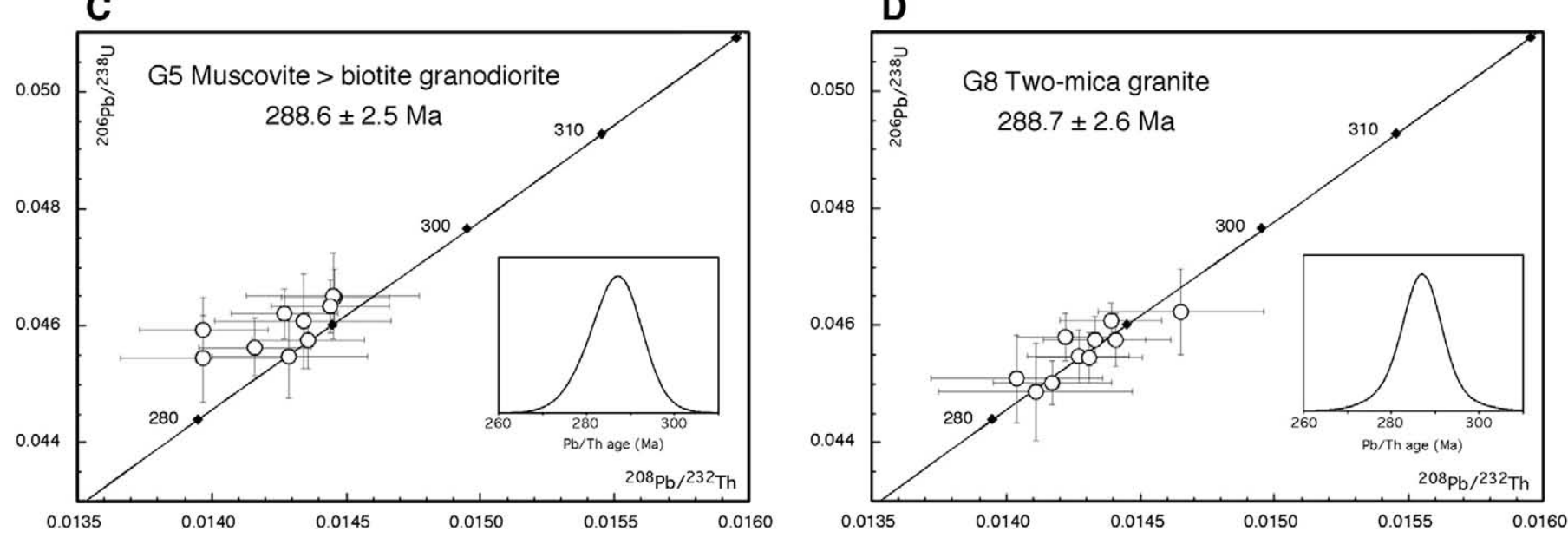

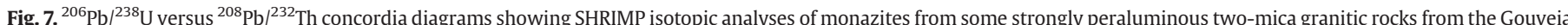


uncertainty in the $\mathrm{Pb} / \mathrm{Th}$ calibration (0.3\%). Insets show relative probability histograms of the ${ }^{208} \mathrm{~Pb} /{ }^{232} \mathrm{Th}$ ages.

The large muscovite flakes from the granitic rocks of the Gouveia area (Table 9) have the composition of primary muscovite (Miller et al., 1981; Monier et al., 1984); they have higher $\mathrm{TiO}_{2}$ contents than the secondary muscovite formed by alteration of plagioclase (Table 9). Plotted against whole-rock total $\mathrm{FeO}$, the variation in some trace elements in the muscovite defines a trend from G5 to G6, and individual trends for G4, G7 and G8 (Fig. 10D-F).

\subsection{Accessory minerals}

Titanite occurs only in granodiorite $\mathrm{G} 1$ and has a homogeneous composition, $\left(\mathrm{Ca}_{3.70} \mathrm{Fe}_{0.10}^{2+}\right)_{\Sigma 3.80}\left(\mathrm{Ti}_{3.80} \mathrm{Al}_{0.09}\right)_{\Sigma 3.89}\left[\mathrm{SiO}_{4}\right](\mathrm{O}, \mathrm{OH}, \mathrm{F})$. Garnet is an early mineral in the crystallization sequence of granite G2. It has a homogeneous almandine-spessartine composition (Alm 78.6

Table 5

SHRIMP U-Th-Pb ages (Ma) of monazite from two-mica granites of the Gouveia area, central Portugal

\begin{tabular}{lll}
\hline Granites & ${ }^{206} \mathrm{~Pb} /{ }^{238} \mathrm{U}$ & ${ }^{208} \mathrm{~Pb} /{ }^{232} \mathrm{Th}$ \\
\hline G3 & $302.8 \pm 2.4(3.6)$ & $303.8 \pm 2.4(3.2)$ \\
G4 & $304.1 \pm 2.9(3.9)$ & $301.4 \pm 1.6(2.6)$ \\
G5 & $290.1 \pm 2.4(3.4)$ & $288.6 \pm 1.5(2.5)$ \\
G8 & $287.7 \pm 2.0(3.1)$ & $288.7 \pm 1.6(2.6)$ \\
\hline
\end{tabular}

The uncertainty without brackets is the internal precision (95\% c.l.). The uncertainty in brackets includes the uncertainty in the $\mathrm{Pb} / \mathrm{U}$ or $\mathrm{Pb} / \mathrm{Th}$ calibration.
$\left.\mathrm{Sp}_{17.3} \mathrm{Pyr}_{3.4} \mathrm{Gros}_{0.7}\right)$. Andalusite and sillimanite occur in the strongly peraluminous granite $\mathrm{G} 6$ (average $\mathrm{A} / \mathrm{CNK}=1.27$ ). The andalusite is relatively pure, containing only $0.40 \mathrm{wt} . \% \mathrm{FeO}$. The sillimanite needles were too fine to analyse. Euhedral andalusite is included in micas. Sillimanite is included in andalusite, muscovite, feldspars and quartz. Therefore, andalusite and sillimanite are early minerals and sillimanite is earlier than andalusite. The euhedral andalusite crystals have similar dimensions to those of other magmatic minerals. Andalusite is in equilibrium with coexisting biotite that has $\mathrm{Al}^{\mathrm{IV}}$ of $1.268 \mathrm{apfu}$ (on the basis of 11 atoms of oxygen). This andalusite corresponds to the cotectic type 2c (water-undersaturated, $T \downarrow$ ) of Clarke et al. (2005).

Schorl from $\mathrm{G} 7$ has a lower $\left(\mathrm{Fe} /(\mathrm{Fe}+\mathrm{Mg})_{\text {atom }}=0.64\right)$ than that of G6 (0.77). In both granites, schorl crystals are homogeneous in composition. Ilmenite from G1 has $0.13 \mathrm{wt} . \% \mathrm{MnO}$, whereas that in the twomica granites has on average 4.26-5.04 wt.\% MnO. Magnetite only occurs in G1 and has the composition of a pure end-member.

\section{Discussion}

\subsection{Early Ordovician biotite granodiorite G1}

The pre-Variscan basement of the Central Iberian Zone (CIZ) contains three main belts of Cambro-Ordovician igneous rocks: a) the metavolcanic rocks and metagranites of the Olho de Sapo Formation; b) the metagranites of the northernmost zone of the SchistGraywacke Domain; c) the Carrascal-Portalegre granitoids and the 
Table 6

$\mathrm{Rb}-\mathrm{Sr}$ and $\mathrm{Sm}-\mathrm{Nd}$ analytical data of granitic rocks from the Gouveia area, central Portugal

\begin{tabular}{llllllll}
\hline $\begin{array}{l}\text { Granitic } \\
\text { rock }\end{array}$ & Sample & $\begin{array}{l}\mathrm{Rb} \\
(\mathrm{ppm})\end{array}$ & $\begin{array}{l}\mathrm{Sr} \\
(\mathrm{ppm})\end{array}$ & ${ }^{87} \mathrm{Rb} /{ }^{86} \mathrm{Sr}$ & $\begin{array}{l}{ }^{87} \mathrm{Sr} / \\
{ }^{86} \mathrm{Sr}\end{array}$ & $\begin{array}{l}\text { Error } \% \\
2 \sigma\end{array}$ & $\begin{array}{l}{ }^{87} \mathrm{Sr} / \\
\text { G1 }\end{array}$ \\
\hline G3 $)_{\mathrm{i}}$
\end{tabular}

G1, G3, G4, G5, G6, G7, G8 as in Table $1 .\left({ }^{87} \mathrm{Sr} /{ }^{86} \mathrm{Sr}\right)_{\mathrm{i}}$ were calculated for G1 (482 Ma), G3 and G4 (303 Ma), G5 and G6 (294 Ma) and G7 and G8 (288 Ma). Data obtained by TIMS.

metavolcanic rocks of the Urra Formation, further south (Bea et al., 2007). Pre-Variscan igneous rocks are rare in Portugal and were previously unknown in the present study area.

Biotite granodiorite G1, emplaced in the Early Ordovician (481.8 \pm $5.9 \mathrm{Ma}$ ), is located in the Schist-Graywacke Domain $\sim 200 \mathrm{~km}$ west from the northernmost zone. Biotite is the only mafic mineral, but G1 also contains titanite and magnetite, is calc-alkalic (Frost et al., 2001) and weakly peraluminous $(\mathrm{A} / \mathrm{CNK}=1.03)$, has low $\left({ }^{87} \mathrm{Sr} /{ }^{86} \mathrm{Sr}\right)_{482}=$ 0.7036, high $\varepsilon \mathrm{Nd}_{482}=+2.5$ and moderate $\delta^{18} \mathrm{O}=8.9 \%$ (Tables 6 and 7), and shows a differentiation trend in variation diagrams for major and trace elements (Fig. 2). It has some characteristics distinct from those of other Pre-Variscan metagranites (Bea et al., 2007), namely higher $\mathrm{Fe} /(\mathrm{Fe}+\mathrm{Mg})$ of $0.79, \mathrm{Na}_{2} \mathrm{O}>\mathrm{K}_{2} \mathrm{O}$ and positive $\varepsilon \mathrm{Nd}_{482}$, but these characteristics are similar to those of the Early Ordovician I-type granitic rocks from the Oledo pluton, central Portugal, located in the same belt of the Central Iberian Zone (Antunes, 2006). Low $\left({ }^{87} \mathrm{Sr} /{ }^{86} \mathrm{Sr}\right)_{482}$ and positive $\varepsilon \mathrm{Nd}_{482}$ indicate that the granite is derived primarily from a relatively depleted mantle source region or isotopically primitive igneous lower crust, although the moderately high $\delta^{18} \mathrm{O}$ precludes a pure mantle source. Possibly mantle-derived magma heated predominantly igneous lower crust at the crust-mantle interface and caused crustal partial melting, after which granitic magma was rapidly transferred to upper crustal levels (Bea et al., 2007). Granodiorite G1 is

Table 7

Whole-rock oxygen isotopic data of granitic rocks from Gouveia area, central Portugal

\begin{tabular}{lllllllll}
\hline & G1 & G2 & G3 & G4 & G5 & G6 & G7 & G8 \\
\hline$\delta^{18} \mathrm{O} \%$ & 8.8 & 12.3 & 13.2 & 12.1 & 10.3 & 11.1 & 12.2 & 11.4 \\
& 8.9 & & 13.5 & 12.1 & 11.0 & 11.2 & 13.3 & 11.5 \\
& & & 13.5 & & & 11.2 & & \\
& & & & & & 11.3 & & \\
\hline
\end{tabular}

Column headings as in Table 1.

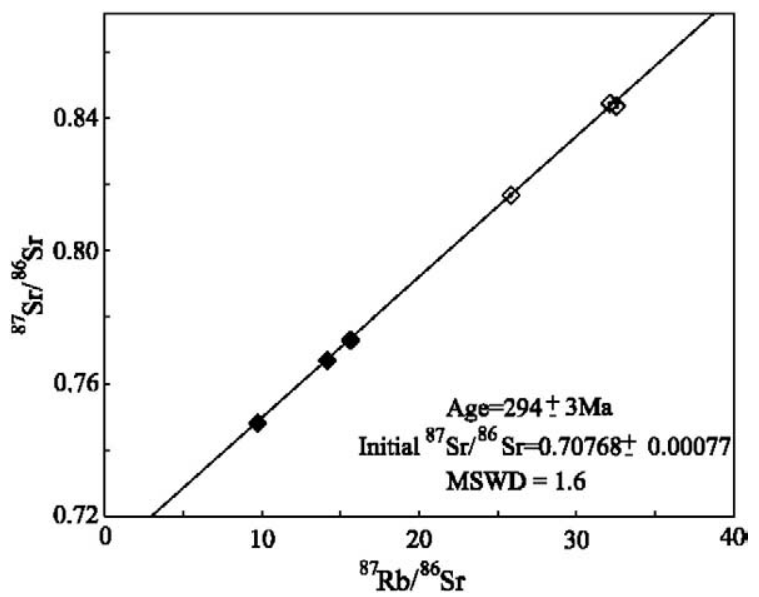

Fig. 8. Whole-rock $\mathrm{Rb}-\mathrm{Sr}$ isochron for muscovite > biotite granodiorite to granite G5 and granite G6. Symbols as in Fig. 2.

undeformed, because is located in the south near Manteigas (Fig. 1), where there was no significant regional deformation.

\subsection{Variscan two-mica granites}

The seven two-mica granites G2-G8 are alkalic-calcic (Frost et al., 2001), strongly peraluminous, with $\mathrm{A} / \mathrm{CNK}$ ranging between 1.16 and 1.34 (except for granodiorite $\mathrm{G} 5, \mathrm{~A} / \mathrm{CNK}=1.06$ ) and $\mathrm{K}_{2} \mathrm{O}>\mathrm{Na}_{2} \mathrm{O}$ (Table 2 ). They contain monazite and $\geq 1.22 \%$ normative corundum, are LREE-enriched, have negative Eu anomalies (Fig. 3), high initial ${ }^{87} \mathrm{Sr} /{ }^{86} \mathrm{Sr}\left(\geq 0.7076\right.$, Table 6) and high $\delta^{18} \mathrm{O}(\geq 10.7 \%$, Table 7$)$.

Significant differences in the monazite $\mathrm{U}-\mathrm{Th}-\mathrm{Pb}$ ages of the twomica granites occur at 305 Ma for G3 and G4, 290 Ma for G5 and G8 (Table 5), suggesting that these granites are related to two separate tectonic events. The former are late-D3 and the latter are post-D3. The last ductile deformation phase D3, of Namurian-Westphalian age, was followed by a brittle deformation phase D4 in the Permian (Pereira et al., 1993), which controlled the emplacement of granites G5-G8. There are no significant mineralogical, chemical (major, trace and REE elements) and isotopic $\left(\left({ }^{87} \mathrm{Sr} /{ }^{86} \mathrm{Sr}\right)_{\mathrm{i}}\right.$ and $\left.\left.\delta^{18} \mathrm{O}\right)\right)$ distinctions between late- and post-D3 two-mica granites, if analytical uncertainties are taken into account. In other Portuguese areas of the CIZ, however, a major change occurred at about 300 Ma between calc-alkaline and alumino-potassic biotite granitoids emplaced between 320 and $300 \mathrm{Ma}$ and subalkaline ferro-potassic biotite granites emplaced at 296-290 Ma (Dias et al., 1998).

Three phases of deformation are recognized in the CIZ. D1 started at about $360 \mathrm{Ma}$ and D2 occurred during the Early-Middle Carboniferous. These correspond to the collisional stage of the Variscan orogeny, with crustal thickening associated with partial melting. The late stage D3 deformation phase is related to strike-slip shear zones (e.g. Abalos et al., 2002). Granite emplacement at 320-300 Ma postdates D2, and is mainly related to D3 (e.g. Dias et al., 1998). In general, the voluminous and widespread 340-300 Ma, collision-related, strongly peraluminous granites $(A / C N K \geq 1.1)$ of the Variscan orogeny of Europe were emplaced after crustal thickening, as almost all post-date an early collision-related medium-pressure metamorphic event (Finger et al., 1997). Portuguese strongly peraluminous two-mica granites (PSPG) that were emplaced in the CIZ during D3 and have been dated by whole-rock $\mathrm{Rb}-\mathrm{Sr}$ isochrons, range in age from 336 $\pm 9 \mathrm{Ma}$ (Neiva, 1993 ) to $287 \pm 7 \mathrm{Ma}$ (Silva and Neiva, 1999/2000). ID-TIMS U-Pb ages of both zircon and monazite from PSPG of the Castelo Branco pluton are $310 \pm 1 \mathrm{Ma}$ (Antunes et al., 2008). Therefore, as is common elsewhere in Europe, the PSPG were emplaced after crustal thickening.

The PSPG from the Gouveia area can be compared with other PSPG of different ages from the CIZ, namely from Gerez at 336 $\pm 9 \mathrm{Ma}$ (Neiva, 

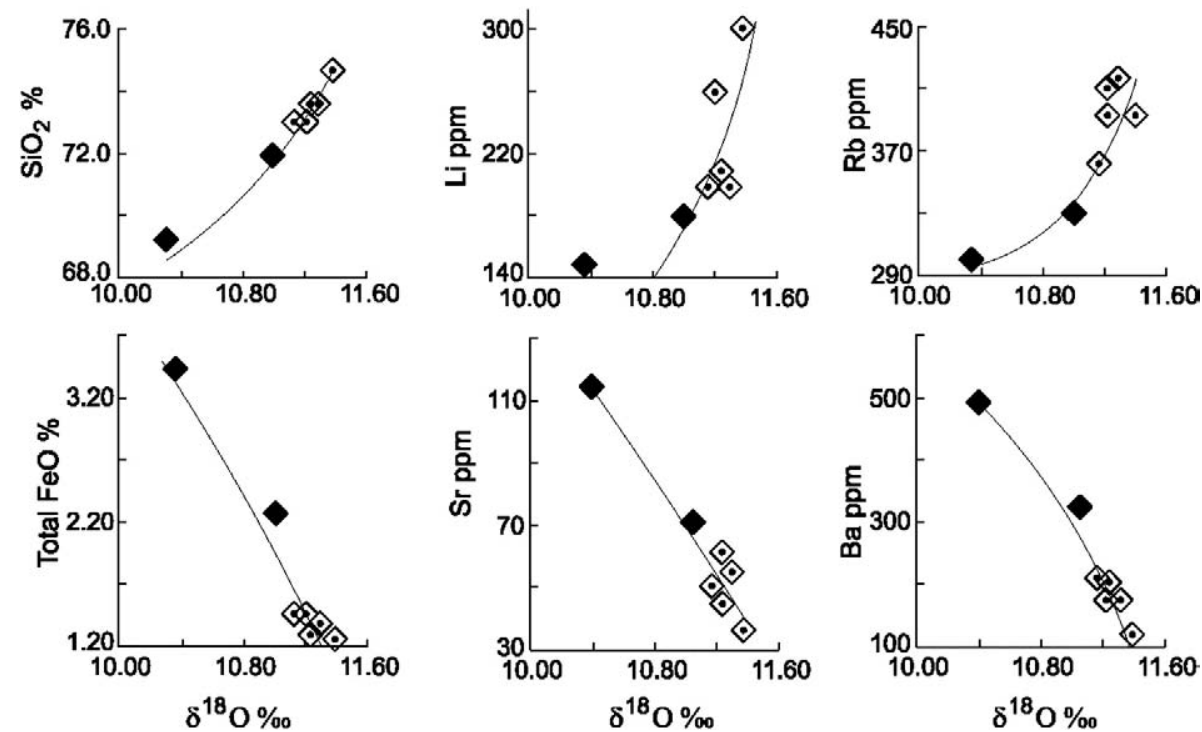

Fig. 9. Selected variation diagrams of $\delta^{18} \mathrm{O}$ for the granodiorite to granite G5 and granite G6 from the Gouveia area. Symbols as in Fig. 2.

1993), Castelo de Paiva at $335 \pm 13$ to $293 \pm 12$ Ma (Neiva, 1998), Ervedosa at $328 \pm 9 \mathrm{Ma}$ (Gomes and Neiva, 2002), Jales at $320 \pm 12$ and $309 \pm 3$ Ma (Neiva, 1992; Neiva et al., 1995), the Castelo Branco pluton at $310 \pm 1 \mathrm{Ma}$ (Antunes et al., 2008) and Carregal do Sal-Nelas-Lagares da Beira from $308 \pm 11$ to $287 \pm 7$ Ma (Silva and Neiva, 1999/2000). Independent of their age, all have similar mineralogical, chemical and isotopic characteristics because most originated by partial melting of metasedimentary materials and some are the products of fractional crystallization of strongly peraluminous granitic magma (e.g. Neiva, 1992).

Granites G5 and G6 seem to be closely related to each other through a magmatic differentiation process, as evidenced by (1) a local gradational contact between the two plutons (Table 1); (2) similar trend lines in variation diagrams for major and trace elements from whole-rocks, trace elements from biotite and muscovite (Figs. 2, 10) and in major and trace elements vs. whole-rock $\delta^{18} \mathrm{O}$ (Fig. 9); (3) subparallel REE patterns (Fig. 3), co-linearity on a whole-rock $\mathrm{Rb}-\mathrm{Sr}$ isochron (Fig. 8) and decreases in plagioclase $\mathrm{Ca}$ and microcline $\mathrm{Ba}$ from G5 to G6 (Table 1).

The intrusive contacts between biotite granodiorite G1 and twomica granite G4 and between most two-mica granites are sharp (Table 1). The whole-rock variation diagrams for $\mathrm{CaO}, \mathrm{F}, \mathrm{Sn}, \mathrm{Li}, \mathrm{Y}, \mathrm{Zn}$ and $\mathrm{Sr}$ show that the fractionation trends defined by G5 and G6 are independent of those individually defined by granites G2, G3 and G4

Table 8

Average chemical analyses in wt.\%, trace elements in ppm of biotite of granitic rocks from Gouveia area, central Portugal

\begin{tabular}{|c|c|c|c|c|c|c|c|c|}
\hline & G1 & G2 & G3 & G4 & G5 & G6 & G7 & G8 \\
\hline$\overline{\mathrm{SiO}_{2}}$ & 36.51 & 36.52 & 36.61 & 34.87 & 35.82 & 36.42 & 36.09 & 35.46 \\
\hline $\mathrm{TiO}_{2}$ & 2.79 & 1.23 & 2.12 & 2.57 & 2.36 & 2.23 & 1.87 & 2.81 \\
\hline $\mathrm{Al}_{2} \mathrm{O}_{3}$ & 15.41 & 21.61 & 20.16 & 18.91 & 19.53 & 19.88 & 21.15 & 19.35 \\
\hline $\mathrm{Fe}_{2} \mathrm{O}_{3}$ & 3.44 & 2.76 & 2.75 & 1.92 & 1.87 & 1.14 & 2.72 & 2.44 \\
\hline $\mathrm{FeO}$ & 15.47 & 20.73 & 21.07 & 22.61 & 22.03 & 23.05 & 21.49 & 20.23 \\
\hline $\mathrm{MnO}$ & 0.17 & 0.36 & 0.02 & 0.12 & 0.25 & 0.36 & 0.77 & 0.34 \\
\hline $\mathrm{MgO}$ & 11.67 & 3.88 & 4.39 & 5.14 & 4.60 & 2.60 & 2.54 & 5.02 \\
\hline $\mathrm{CaO}$ & - & - & - & 0.05 & 0.06 & 0.01 & - & - \\
\hline $\mathrm{Na}_{2} \mathrm{O}$ & - & - & - & 0.05 & - & - & - & 0.03 \\
\hline $\mathrm{K}_{2} \mathrm{O}$ & 9.90 & 8.78 & 8.73 & 9.35 & 9.39 & 9.42 & 8.81 & 9.42 \\
\hline $\mathrm{Cl}$ & 0.03 & 0.02 & 0.02 & 0.10 & 0.02 & 0.04 & 0.02 & 0.02 \\
\hline \multirow[t]{2}{*}{$\mathrm{F}$} & 0.39 & 0.56 & 0.61 & 0.60 & 0.76 & 0.74 & 0.37 & 0.45 \\
\hline & 95.78 & 96.45 & 96.48 & 96.29 & 96.69 & 95.89 & 95.83 & 95.57 \\
\hline $\mathrm{O} \equiv \mathrm{Cl}$ & 0.01 & - & - & 0.02 & - & 0.01 & - & - \\
\hline $\mathrm{O} \equiv \mathrm{F}$ & 0.16 & 0.24 & 0.26 & 0.25 & 0.32 & 0.31 & 0.06 & 0.19 \\
\hline Total & 95.61 & 96.21 & 96.21 & 96.02 & 96.36 & 95.57 & 95.76 & 95.38 \\
\hline $\mathrm{Cr}$ & 98 & & & 69 & 50 & 16 & & 49 \\
\hline V & 336 & & & 136 & 157 & 49 & & 149 \\
\hline $\mathrm{Nb}$ & 11 & & & 150 & 190 & 271 & & 189 \\
\hline $\mathrm{Zn}$ & 301 & & & 835 & 646 & 1144 & & 968 \\
\hline Sn & 4 & & & 39 & 93 & 117 & & 62 \\
\hline $\mathrm{Li}$ & 455 & & & 1508 & 2197 & 3789 & & 3360 \\
\hline $\mathrm{Ni}$ & 39 & & & 23 & 9 & 6 & & 11 \\
\hline $\mathrm{Zr}$ & 24 & & & 16 & 25 & 68 & & 36 \\
\hline $\mathrm{Cu}$ & 18 & & & 24 & 30 & 41 & & 26 \\
\hline Sc & 50 & & & 18 & 37 & 7 & & 15 \\
\hline $\mathrm{Ba}$ & 834 & & & 152 & 256 & 105 & & 355 \\
\hline $\mathrm{Rb}$ & 446 & & & 1323 & 1610 & 2077 & & 1583 \\
\hline
\end{tabular}

Column headings as in Table 1. - not detected. Major elements determined by EPMA $\mathrm{FeO}$ by titration and trace elements by ICP-MS on biotite separates.

Table 9

Average chemical analyses in wt.\% and trace elements in ppm of muscovites of granitic rocks from Gouveia area, central Portugal

\begin{tabular}{|c|c|c|c|c|c|c|c|c|}
\hline \multicolumn{8}{|c|}{ Tabular muscovite } & \multirow{2}{*}{$\begin{array}{l}\text { Secondary } \\
\text { muscovite }\end{array}$} \\
\hline & G2 & G3 & G4 & G5 & G6 & G7 & G8 & \\
\hline$\overline{\mathrm{SiO}_{2}}$ & 47.20 & 47.16 & 47.25 & 46.75 & 47.16 & 46.85 & 47.11 & 46.95 \\
\hline $\mathrm{TiO}_{2}$ & 0.13 & 0.42 & 0.62 & 0.96 & 0.34 & 0.30 & 0.61 & 0.02 \\
\hline $\mathrm{Al}_{2} \mathrm{O}_{3}$ & 36.36 & 35.87 & 35.64 & 33.97 & 35.16 & 36.03 & 35.16 & 33.43 \\
\hline $\mathrm{FeO}$ & 1.14 & 1.25 & 1.25 & 1.89 & 1.61 & 1.35 & 1.34 & 2.92 \\
\hline $\mathrm{MnO}$ & - & - & - & - & 0.01 & 0.01 & 0.01 & 0.01 \\
\hline $\mathrm{MgO}$ & 0.21 & 0.50 & 0.51 & 0.99 & 0.49 & 0.42 & 0.56 & 0.92 \\
\hline $\mathrm{CaO}$ & - & 0.01 & 0.03 & 0.03 & 0.01 & - & 0.01 & 0.03 \\
\hline $\mathrm{Na}_{2} \mathrm{O}$ & - & 0.01 & 0.02 & - & 0.12 & 0.03 & 0.02 & 0.03 \\
\hline $\mathrm{K}_{2} \mathrm{O}$ & 10.93 & 10.89 & 10.99 & 10.74 & 10.47 & 10.76 & 10.88 & 10.90 \\
\hline \multirow[t]{2}{*}{$\mathrm{F}$} & 0.27 & 0.20 & 0.26 & 0.90 & 1.00 & 0.42 & 0.51 & n.d. \\
\hline & 96.24 & 96.31 & 96.57 & 96.23 & 96.37 & 96.17 & 96.21 & 95.21 \\
\hline $\mathrm{O} \equiv \mathrm{F}$ & 0.11 & 0.08 & 0.11 & 0.38 & 0.42 & 0.18 & 0.21 & \\
\hline Total & 96.13 & 96.23 & 96.46 & 95.85 & 95.95 & 95.99 & 96.00 & \\
\hline $\mathrm{Cr}$ & & & 11 & 19 & 10 & 14 & 25 & \\
\hline V & & & 47 & 87 & 33 & 18 & 107 & \\
\hline $\mathrm{Nb}$ & & & 34 & 69 & 103 & 93 & 67 & \\
\hline $\mathrm{Zn}$ & & & 65 & 59 & 93 & 90 & 93 & \\
\hline Sn & & & 63 & 125 & 169 & 173 & 103 & \\
\hline $\mathrm{Li}$ & & & 225 & 558 & 1018 & 1030 & 835 & \\
\hline $\mathrm{Ni}$ & & & 5 & 5 & 5 & 5 & 6 & \\
\hline $\mathrm{Zr}$ & & & 5 & 10 & 11 & 6 & 12 & \\
\hline $\mathrm{Cu}$ & & & 11 & 13 & 6 & 5 & 13 & \\
\hline Sc & & & 19 & 71 & 29 & 29 & 43 & \\
\hline $\mathrm{Ba}$ & & & 236 & 316 & 104 & 60 & 269 & \\
\hline $\mathrm{Rb}$ & & & 674 & 898 & 1266 & 945 & 854 & \\
\hline
\end{tabular}

Column headings as in Table 1 . $\mathrm{FeO}=$ total $\mathrm{FeO}$; - not detected; n.d.-not determined. Secondary muscovite is of alteration of plagioclase. Major elements determined by EPMA, and trace elements by ICP-MS on muscovite separates. 

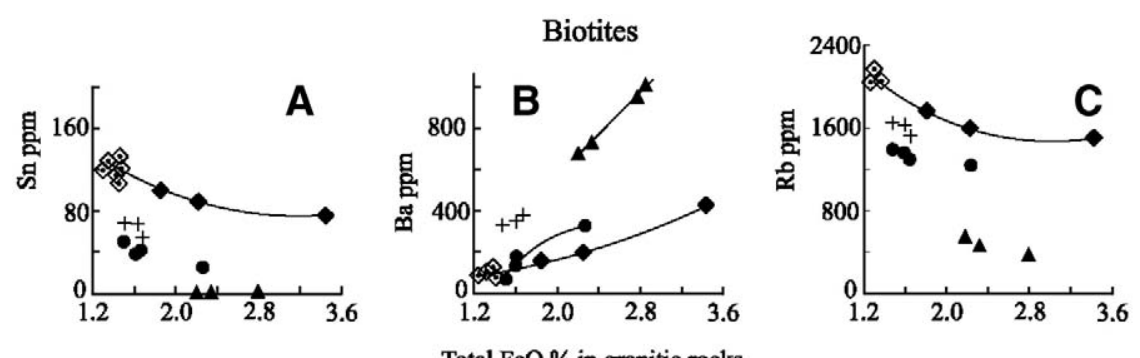

Total $\mathrm{FeO} \%$ in granitic rocks

Muscovites
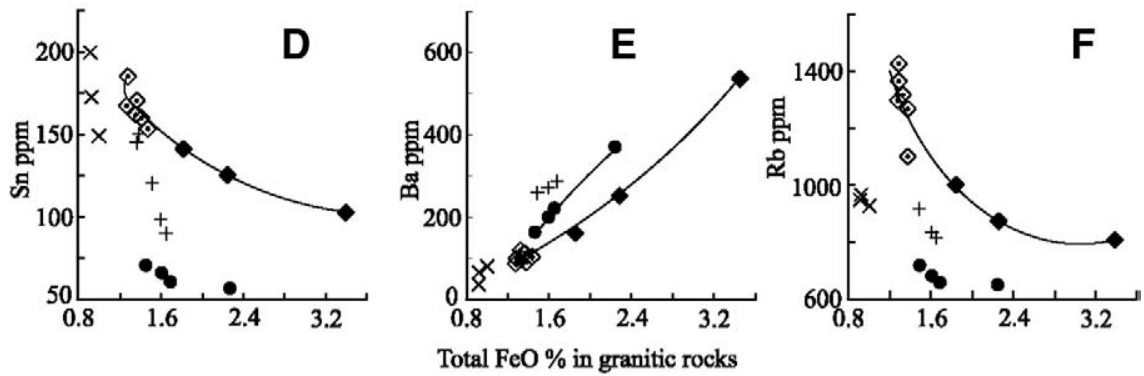

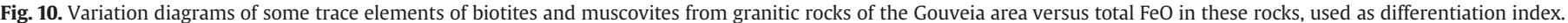
Symbols as in Fig. 2.

(Fig. 2). Although the youngest granites G7 and G8 plot close to other two-mica granites, whole-rock diagrams for Ca, F, Y, Zn and $\mathrm{Sr}$ (Fig. 2) show that they cannot be related to them. As G8 is younger than G7, both must also derive from distinct magma batches. Variation diagrams for Sn, Ba and Rb of biotite and muscovite (Fig. 10), wholerock REE patterns that mostly cut each other (Fig. 3), differences in $\left({ }^{87} \mathrm{Sr} /{ }^{86} \mathrm{Sr}\right)_{\mathrm{i}}$ ratios for G3-G5 and G8 (Table 6) and irregular differences in $\delta^{18} \mathrm{O}$ values for all the two-mica granites from the oldest G2 to the youngest G8 (Table 7), support the conclusion that granites G2-G5, G7 and G8 were derived from different magma batches.

It can be tested whether the two-mica granites G2-G5, G7 and G8 might have resulted from different degrees of partial melting of a fixed volume of crust. With increasing degrees of partial melting, such a process would produce a sequence of magmas that became progressively more mafic and contained more $\mathrm{Fe}, \mathrm{Mg}, \mathrm{Ca}, \mathrm{Ba}, \mathrm{Zr}$ and $\mathrm{Ce}$, and less Si (e.g. Holtz and Barbey, 1991; Bogaerts et al., 2003). From G2 to
$\mathrm{G} 4$, with a progressive decrease in $\mathrm{Si}$, a progressive rise in $\mathrm{Ti}, \mathrm{Fe}, \mathrm{Mg}, \mathrm{Zr}$ and Ba occurs (Table 2), such that G4 might represent the highest degree of partial melting at the highest temperature. However, F and LREE contents also increase progressively, indicating the G4 might represent the lowest degree of partial melting (e.g. Williamson et al., 1996). This inconsistency makes it unlikely that these three granites represent a batch melting series, a conclusion supported by the differences in their $\left({ }^{87} \mathrm{Sr} /{ }^{86} \mathrm{Sr}\right)_{\mathrm{i}}$ (Table 6) and whole-rock $\delta^{18} \mathrm{O}$ (Table 7). Granites G5 and G8 are significantly younger than G3 and G4 (Table 5). Granites G7 and G8 have higher Si and Li contents and lower Ti, Fe, Mg, Ca, Zr, F and LREE contents than G5 (Table 2), indicating that G5, G7 and G8 cannot result from increasing degrees of partial melting of a single source, a conclusion again supported by the differences in their ${ }^{87} \mathrm{Sr} /$ $\left.{ }^{86} \mathrm{Sr}\right)_{\mathrm{i}}$ and $\delta^{18} \mathrm{O}$ (Tables 6, 7).

Major and trace elements were used to test whether G5 and G6 were related through fractional crystallization. The most mafic sample
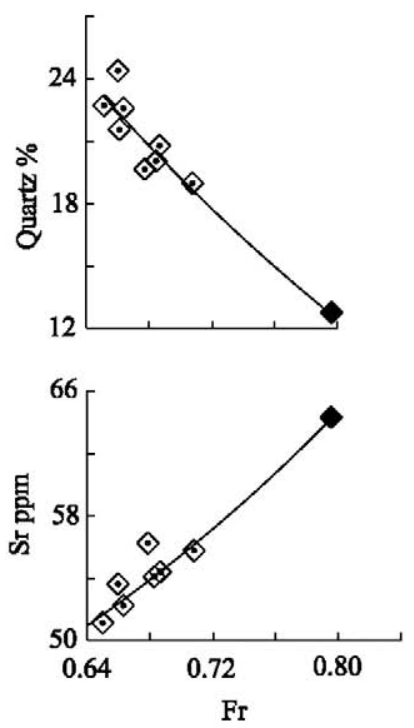
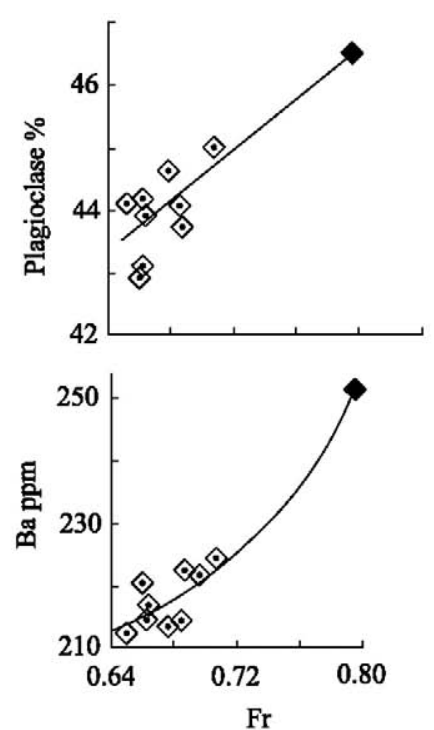
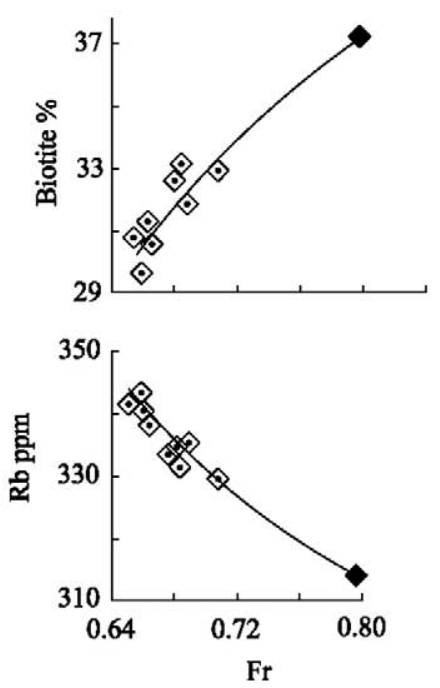

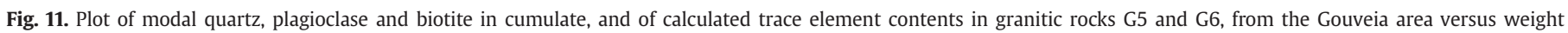
fractionation of remaining melt during fractional crystallization. Symbols as in Fig. 2. Fr-weight fraction of remaining melt during fractional crystallization. 
Table 10

Results of fractional crystallization modelling of the S-type granodiorite G5 from Gouveia area, central Portugal

\begin{tabular}{|c|c|c|c|c|c|}
\hline & \multirow{2}{*}{$\begin{array}{l}\text { Determined parent } \\
\text { granodiorite magma } \\
\text { G5 }\end{array}$} & \multicolumn{4}{|c|}{$\begin{array}{l}\text { Calculated composition of parent } \\
\text { magma for granites }\end{array}$} \\
\hline & & $\overline{\mathrm{G} 5}$ & $R$ & G6 & $R$ \\
\hline$\overline{\mathrm{SiO}_{2}}$ & 69.70 & 69.80 & -0.5 & 69.90 & -0.5 \\
\hline $\mathrm{TiO}_{2}$ & 0.69 & 0.80 & -0.6 & 0.90 & -0.4 \\
\hline $\mathrm{Al}_{2} \mathrm{O}_{3}$ & 14.80 & 15.10 & -1.7 & 15.40 & -1.7 \\
\hline $\mathrm{Fe}_{2} \mathrm{O}_{3} \mathrm{t}$ & 3.86 & 4.00 & -0.5 & 4.10 & -0.7 \\
\hline $\mathrm{MgO}$ & 0.80 & 0.70 & +1.4 & 0.70 & +0.8 \\
\hline $\mathrm{CaO}$ & 1.86 & 1.70 & +1.2 & 1.40 & +1.1 \\
\hline $\mathrm{Na}_{2} \mathrm{O}$ & 3.52 & 3.40 & +1.0 & 3.20 & +0.9 \\
\hline $\mathrm{K}_{2} \mathrm{O}$ & 4.76 & 4.70 & +0.5 & 4.40 & +0.9 \\
\hline $\mathrm{Fr}$ & & $0.797 \pm 0.053$ & & $0.663 \pm 0.107$ & \\
\hline \multicolumn{6}{|c|}{ Modal composition of cumulate } \\
\hline Quartz & & $12.4 \pm 10.9$ & & $22.5 \pm 13.3$ & \\
\hline Plagioclas & & $46.5 \pm 5.6$ & & $44.0 \pm 20.9$ & \\
\hline Biotite & & $37.1 \pm 6.9$ & & $30.5 \pm 8.9$ & \\
\hline Ilmenite & & $4.0 \pm 2.0$ & & $3.0 \pm 2.7$ & \\
\hline \multicolumn{6}{|c|}{ Composition of residual melts } \\
\hline ppm & Det. & Det. & Calc. & Det. & Calc. \\
\hline $\mathrm{Sr}$ & 112 & 62 & 64 & 60 & 52 \\
\hline $\mathrm{Ba}$ & 486 & 203 & 251 & 195 & 217 \\
\hline $\mathrm{Rb}$ & 300 & 394 & 314 & 406 & 340 \\
\hline
\end{tabular}

G5-Coarse-grained porphyritic muscovite> biotite granodiorite-granite; G6-mediumto coarse-grained slightly porphyritic muscovite> biotite granite. $\mathrm{Fe}_{2} \mathrm{O}_{3}$ t-total $\mathrm{Fe}_{2} \mathrm{O}_{3}$. $\mathrm{Fr}-$ fraction of weight melt remaining during fractional crystallization. $\mathrm{R}$ represents the prediction of error on the calculated value, so represents $X_{\text {determined }}-X_{\text {calculated }} /$

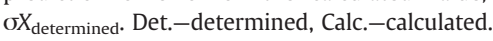

of granodiorite G5 was selected as the parent magma, and the compositions of other samples of granites G5 and G6, which do not show any metasomatic effects (secondary muscovite and chlorite), were taken as the residual liquids. Compositions of microcline, micas and ilmenite determined by electron microprobe analyses and pure anorthite, albite and quartz were used in the modelling. The percentage of quartz increases and that of plagioclase and biotite decreases in the cumulate with the decrease in weight fraction of remaining melt during fractional crystallization from granodiorite G5 to granite G6 (Fig. 11, Table 10). The anorthite content of plagioclase in the cumulate is always similar to that of the core of plagioclase phenocrysts in granodiorite G5.

The $\mathrm{Sr}$, Ba and $\mathrm{Rb}$ contents of the residual melts were calculated using the concentration of each element in granodiorite G5, the modal composition of cumulate, the weight fraction of remaining melt during fractional crystallization, as well as the distribution coefficients for $\mathrm{Sr}$, $\mathrm{Ba}$ and $\mathrm{Rb}$ in biotite given by Icenhower and London (1995), for $\mathrm{Sr}$ and $\mathrm{Ba}$ in plagioclase given by Blundy and Wood (1991), and for Rb in plagioclase given by Nash and Crecraft (1985). Sr and Ba decrease, and $\mathrm{Rb}$ increases as the weight fraction of remaining melt decreases from G5 to G6 during fractional crystallization (Fig. 11, Table 10). The bulk distribution of $\mathrm{Ba}$ and $\mathrm{Rb}$ is mainly controlled by biotite, while that of $\mathrm{Sr}$ is essentially controlled by plagioclase. The calculated and measured values for $\mathrm{Sr}$ are very similar (Table 10 ), but the calculated Ba values are higher than measured and the calculated $\mathrm{Rb}$ values are lower, probably because the distribution coefficients have large uncertainties. Granite G6 was derived from the granodiorite G5 magma by fractional crystallization of plagioclase, biotite, quartz and ilmenite (Table 10).

Most REE in granites are concentrated in accessory minerals. The decrease in LREE from G5 to G6 (Fig. 3) might be due to fractionation of monazite, the decrease in MREE can be attributed to fractionation of apatite and zircon, and the decrease in HREE can be explained by fractionation of zircon (e.g. Yurimoto et al., 1990). This is consistent with the decrease in $\mathrm{Zr}$ content from G5 to G6 (Table 2).
G6 has a much higher $\mathrm{Rb} / \mathrm{Sr}$ than $\mathrm{G} 5$, so the calculation of initial ${ }^{87} \mathrm{Sr} /{ }^{86} \mathrm{Sr}$ is highly age-dependent. However, the six whole-rock analyses from the two granites plot within error on a single $\mathrm{Rb}-\mathrm{Sr}$ isochron (Fig. 8), giving an age $(293.8 \pm 3.4 \mathrm{Ma})$ indistinguishable from the G5 monazite age $(288.6 \pm 2.5 \mathrm{Ma})$, consistent with both granites having the same $\left({ }^{87} \mathrm{Sr} /{ }^{86} \mathrm{Sr}\right)_{294},(0.7077 \pm 0.0008)$ and hence being cogenetic. The rise in the mean $\delta^{18} \mathrm{O}$ value from G5 to G6 (Fig. 9) is within the range for a fractional crystallization process (e.g. White, 2003) and is explicable in terms of that process.

The two-mica granites G2-G5, G7 and G8 contain metasedimentary enclaves (Table 1$)$ and their $\left({ }^{87} \mathrm{Sr} /{ }^{86} \mathrm{Sr}\right)_{\mathrm{i}}$ and $\delta^{18} \mathrm{O}$ values (Tables 6,7 ) are consistent with an origin by partial melting of metasedimentary crustal rocks (Chappell and White, 1992). Small differences between these isotopic values, and the wide range of Th/U and age $(\sim 2.1-0.35 \mathrm{Ga})$ in abundant inherited zircon cores that will be reported elsewhere, indicate that the source materials were heterogeneous. As most of these granites have $\mathrm{CaO} / \mathrm{Na}_{2} \mathrm{O}$ ratios ranging between 0.13 and 0.27 , they were produced from clay-rich sources (plagioclase-poor), suggesting that they are magmas derived from pelites (Sylvester, 1998). G5 and G8, however, have higher $\mathrm{CaO} / \mathrm{Na}_{2} \mathrm{O}$ ratios (0.42 and 0.38 respectively), indicating that they might be derived from partial melting of pelites containing a clay-poor sediment component such as graywacke. Granites produced by dehydration melting of felsic metapelites are characterized by relatively low concentrations of $\mathrm{Al}_{2} \mathrm{O}_{3}+\mathrm{FeO}+\mathrm{MgO}+\mathrm{TiO}_{2}$ of $15-18 \mathrm{wt} . \%$ and an elevated $\mathrm{Al}_{2} \mathrm{O}_{3} /\left(\mathrm{FeO}+\mathrm{MgO}+\mathrm{TiO}_{2}\right)$ ratio of $10-25$ (Sylvester, 1998; Patiño Douce, 1999). The two-mica granites from the Gouveia area have $\mathrm{Al}_{2} \mathrm{O}_{3}+\mathrm{FeO}+\mathrm{MgO}+\mathrm{TiO}_{2}$ ranging between 15 and $17 \mathrm{wt} . \%$ and the $\mathrm{Al}_{2} \mathrm{O}_{3} /\left(\mathrm{FeO}+\mathrm{MgO}+\mathrm{TiO}_{2}\right)$ ratio is 25 for $\mathrm{G} 2,13$ for $\mathrm{G} 3$ and 17 for $\mathrm{G} 7$, confirming that they are derived from felsic metapelites. The ratio is much lower in G4, G5 and G8 (6, 5 and 7 respectively), consistent with the derivation of those granites from a source containing both metapelite and metagraywacke. The two-mica granites were emplaced in the Cambrian schist-metagraywacke complex, consisting of phyllite with intercalations of metagraywacke and marble which may have been the source, but younger material was also involved, as indicated by ages as low as $\sim 350$ Ma that we have measured on some zircon cores.

The crustal partial melting event cannot have been caused by the introduction of heat by mafic magma intruded into the crust from below-a large amount of mafic magma would have been necessary, yet the two-mica granites are isotopically evolved and contain only rare microgranular enclaves. The crust partially melted as a result of the high geothermal gradient produced by orogenesis and tectonic events in the Late Carboniferous (Asturian) and the Early Permian (Saalinian), which explains the significant differences in the monazite $\mathrm{U}-\mathrm{Th}-\mathrm{Pb}$ ages of the two-mica granites at $\sim 305 \mathrm{Ma}$ for G3 and G4 and 290 Ma for G5 and G8. Therefore, these granites are derived by partial melting of heterogeneous crustal materials caused by crustal thickening and two distinct tectonic events.

The chemical compositions of the large muscovite flakes from the Variscan granites of the Gouveia area (Table 9) show that muscovite is magmatic which is confirmed by the variation in some trace elements in muscovite versus whole-rock total $\mathrm{FeO}$ (Fig. 10). The Si content of white micas coexisting with K-feldspar, quartz and phlogopite increases with pressure (e.g. Massonne and Szpurka, 1997). The Si contents of the analysed magmatic muscovites are mostly 3.1 apfu (on the basis of 11 oxygens).

The magma temperature during the growth of muscovite can be estimated by assessing the solidus temperature in the haplogranite system. Excess $\mathrm{Al}_{2} \mathrm{O}_{3}$ lowers the haplogranite solidus by about $30{ }^{\circ} \mathrm{C}$ (Clarke et al., 2005). Fluorine, Li and B also lower the solidus (e.g. Manning, 1981; London and Burt, 1982; Pichavant and Manning, 1984; Kawakami, 2001). The granites from the Gouveia area contain up to 0.18 wt.\% F, 242 ppm Li and abundant magmatic muscovite (Tables 1,2). The intersections of the curve for granitic melts (Johannes and Holtz, 

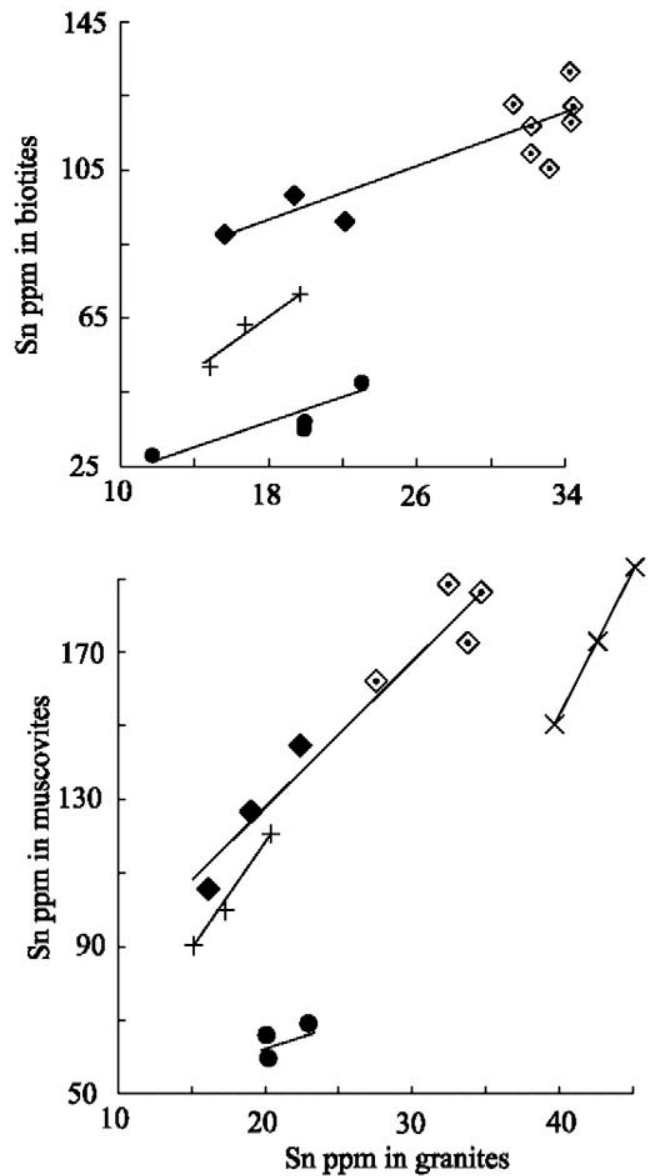

Fig. 12. Plots of $S n$ in granites versus $S n$ in biotite and muscovite from the Gouveia area. Symbols as in Fig. 2.

1996) and the Si-isopleths for muscovite containing 3.1 apfu Si (Massone and Schreyer, 1987; Massone and Szpurka, 1997) are about 633 and $625{ }^{\circ} \mathrm{C}$ (estimated from Klein et al., 2008).

Application of the Si-in phengite barometer (Massone and Schreyer, 1987; Massone and Szpurka, 1997) gives an estimated emplacement pressure of $4.5-4.8 \mathrm{~kb}$ which, assuming a density of $2.8 \mathrm{~g} / \mathrm{cm}^{3}$ for the mainly phyllitic hanging-wall rocks (Neiva et al., 1990), corresponds to a minimum intrusion depth of $17-18 \mathrm{~km}$. This pressure estimate depends on the assumed crystallization temperature for muscovite. Granite G6 contains magmatic muscovite and andalusite, which are stable in this pressure range (Clarke et al., 2005).

The granites were emplaced under relatively reducing $\mathrm{f}_{\mathrm{O} 2}$ conditions, as they contain ilmenite. The late- and post-D3 two-mica granites from the Gouveia area were emplaced at similar $P-T$ and depth conditions at mid-crustal levels. Variscan two-mica granites from northern Portugal and the western Bohemian Massif, Germany, also intruded to mid-crustal levels (Beetsma, 1995; Klein et al., 2008), whereas Variscan biotite granites from the Massif Central, France, were formed by partial melting of the lower crust (e.g., Downes et al., 1987).

\subsection{Origin of the high Sn content in the granites}

The average Sn content of the unaltered two-mica granites from the Gouveia area ranges from 16 to $40 \mathrm{ppm}$ (Table 2), identifying them as Sn-bearing granites in the sense of Lehmann (1990). The Sn content of all the two-mica granites is negatively correlated with total $\mathrm{FeO}$ (Fig. 2), showing that fractional crystallization caused an increase in the Sn content of each granite magma. During fractional crystallization of granodiorite G5, there was an increase in Sn content from
16 to $34 \mathrm{ppm}$, reached in granite G6 (Fig. 2). Sn-bearing aplitepegmatite sills derived from the G8 magma by fractional crystallization of quartz, plagioclase, potassium feldspar and biotite contain up to $47 \mathrm{ppm}$ Sn, which is retained in micas, as cassiterite was not found (Neiva et al., 2008). There was an increase in Sn content from 15 to $47 \mathrm{ppm}$.

Fractional crystallization is well-known to be a very important mechanism in the production of Sn-bearing granites (Lehmann, 1982; Neiva, 1984; Lehmann, 1987, 1990; Sawka et al., 1990; Blevin and Chappell, 1995; Neiva, 2002; Gomes and Neiva, 2002). The weakly peraluminous biotite granodiorite G1 has a Sn content below the detection limit of $4 \mathrm{ppm}$. Although it shows fractionation trends for major and trace elements (Fig. 2), Sn is very low even in the most evolved sample of this granodiorite (Table 2). Among the strongly peraluminous two-mica granites, G4 is the granite that has the lowest Sn content (8 ppm), which increased up to $23 \mathrm{ppm}$ by fractional crystallization (Fig. 2). The country rock phyllite consisting of quartz, muscovite, biotite, chlorite, albite, zircon, rutile and ilmenite contains 4 ppm Sn (Ramos, 1998). The initial Sn content of the granite magma depends on the initial Sn content of the metasediment that partially melted, the mineral phases that broke down to release the Sn and the bulk distribution coefficients. The two-mica granites are products of melting of mica-rich sources. Initially strongly peraluminous magmas can fractionate to produce strong Sn enrichments, but most initially metaluminous (and possibly weakly peraluminous) magmas do not.

The Sn contents of the two-mica granites are positively correlated with the Sn contents of their micas (Fig. 12). Tin contents in biotite and muscovite from granites G4 and G8, and the sequence formed by G5 and G6, increase as whole-rock total FeO decreases (Fig. 10). Therefore, fractional crystallization also causes an increase in Sn contents of micas. The distribution coefficient of Sn between micas (Bt and Ms) and whole-rock $(\mathrm{Wr})$ is 2-4 for $\mathrm{D}(\mathrm{Sn})^{\mathrm{Bt} / \mathrm{Wr}}$ and $4-6$ for $\mathrm{D}(\mathrm{Sn})^{\mathrm{Ms} / \mathrm{Wr}}$, the highest values being in the sequence defined by granites G5 and G6. The partition coefficient for $\mathrm{Sn}$ between coexisting biotite and muscovite from granites $\mathrm{G} 5$ and $\mathrm{G} 6$ is $\mathrm{D}(\mathrm{Sn})^{\mathrm{Bt} / \mathrm{Ms}}=0.7$. Mica is the principal host for Sn in the two-mica granites. Muscovite has a higher Sn content than coexisting biotite (Tables 8 and 9), as generally found elsewhere in Iberian Sn-bearing granites (Neiva 2002).

The ratio $\mathrm{Rb} / \mathrm{Sr}$ is taken as an independent indicator of the degree of magmatic differentiation. Correlation lines have only been drawn for the granitic rocks G3, G4, G5-G6, G7 and G8 (Fig. 13) where the correlation as a function of the number of data and the correlation coefficient can be considered valid at $99 \%$ probability. The correlation lines follow essentially Sn enrichment patterns in accordance with a fractional crystallization model. The fractionation trends are traceable

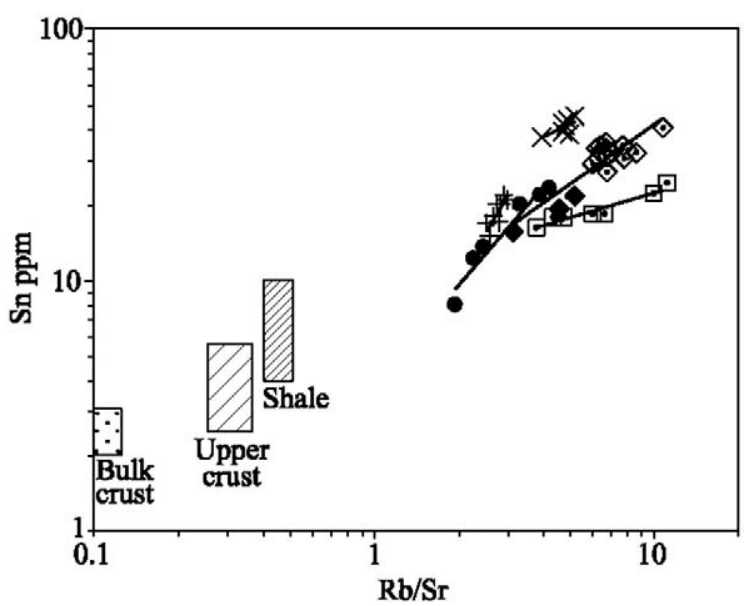

Fig. 13. Correlation of $\log \mathrm{Rb} / \mathrm{Sr}-\log \mathrm{Sn}$ for granitic rocks of the Gouveia area. Global reference fields from Lehmann (1990). Symbols as in Fig. 2. 
back to $4 \mathrm{ppm} \mathrm{Sn}$ in the least evolved portions. Therefore, a primary Sn enrichment beyond average shale composition is not justified (Lehmann, 1990) and consequently the Gouveia area does not represent a crustal anomaly in $\mathrm{Sn}$, which is supported by the $4 \mathrm{ppm}$ Sn content of the country phyllite. The different slopes of the fractionation trends are caused by the degree of Sn enrichment during magmatic differentiation. The low $\mathrm{f}_{\mathrm{O}_{2}}$ favors enrichment of $\mathrm{Sn}$ in residual liquids (e.g. Ishihara et al., 1980; Lehmann, 1990).

\section{Conclusions}

1) Biotite granodiorite G1 from the Gouveia area is calc-alkalic and weakly peraluminous, has a U-Pb zircon age of $481.8 \pm 5.9 \mathrm{Ma}$ (Early Ordovician), and its $\left({ }^{87} \mathrm{Sr} /{ }^{86} \mathrm{Sr}\right)_{482}, \varepsilon \mathrm{Nd}_{\mathrm{T}}$ and $\delta^{18} \mathrm{O}$ values show that it is sourced primarily from igneous rocks derived from depleted mantle or meta-igneous lower crust.

2) The two-mica granites are alkalic-calcic and strongly peraluminous. Some are late-D3 and have monazite $\mathrm{U}-\mathrm{Th}-\mathrm{Pb}$ ages of $\sim 305 \mathrm{Ma}$ and others are post-D3 and $\sim 290 \mathrm{Ma}$, but they do not show significant chemical and isotopic distinctions. They have similar mineralogical, chemical and isotopic characteristics to those of syn-late- and post-D3 two-mica granites from other Portuguese areas of the Central Iberian Zone.

3) Most of the two-mica granites have sharp intrusive contacts and display individual fractionation trends for major and trace elements, showing that they are not cogenetic. This is confirmed by biotite and muscovite trends for trace elements and the granite REE patterns, which cut each other in LREE and HREE.

4) The two-mica granites G2-G5 are $305 \mathrm{Ma}$ and late-D3 and G7 and G8 are $290 \mathrm{Ma}$ and controlled by D4. They correspond to different pulses of granite magma, as evidenced by their different $\left({ }^{87} \mathrm{Sr} /{ }^{86} \mathrm{Sr}\right)_{\mathrm{i}}$ ratios and $\delta^{18} \mathrm{O}$ values and major, trace and REE element contents. These indicate that the granites were derived by partial melting of heterogeneous metasediments, mainly metapelites, but also some metagraywackes. Melting occurred in the mid-crust as a result of the high geothermal gradients caused by crustal thickening and two distinct tectonic events, one in the Late Carboniferous (Asturian) and the other in the Early Permian (Saalinian).

5) The major and trace element compositions of two-mica granites G5 and G6 lie on fractionation trends. The trace element contents of their micas also define fractionation trends. Both granites lie on a single whole-rock $\mathrm{Rb}-\mathrm{Sr}$ isochron. G6 was derived from G5 magma by fractionation of plagioclase, biotite, quartz and ilmenite. Fractional crystallization was not accompanied by assimilation of metasediments, as G5 and G6 have the same $\left({ }^{87} \mathrm{Sr} /{ }^{86} \mathrm{Sr}\right)_{294}$.

6) Variscan Sn-bearing two-mica granites from the Gouveia area do not represent a crustal anomaly in Sn. Fractional crystallization increased the Sn content of the magmas, and muscovite is the main host for $\mathrm{Sn}$ in the rocks.

\section{Acknowledgements}

Thanks are due to Eng. M. E. Moreira and Dr. M. J. Canto for XRF and ICP-AES data, respectively; Prof. F. Longstaffe for the determinations of oxygen isotope analyses; Prof. P. Pilar Montero for the $\mathrm{Rb}-\mathrm{Sr}$ and Sm-Nd isotopic analyses; Prof. C.M.B. Henderson for the facilities given to A. Neiva to use two electron-microprobes at the Department of Earth Sciences, University of Manchester, U.K. We also thank Dr. Peter Holden for overseeing the session of analyses on the SHRIMP RG. This work was undertaken as part of a research collaboration between staff of the Australian National University and the University of Coimbra. This research was financially supported by the Geosciences Centre and project POCTI/35602/CTA/99 of FCT. Thanks are due to Profs. F. Bussy, B. Clarke, F. Finger, S. Jung and N. Eby for their helpful comments.

\section{References}

Abalos, B., Carreras, J., Druguet, E., Escuder Viruete, J., Gómez Pugnaire, M.T., Lorenzo Alvarez, S., Quesada, C., Rodríguez Fernández, L.R., Gil-Ibarguchi, J.I., 2002. Variscan and pre-Variscan tectonics. In: Gibbons, W., Moreno, T. (Eds.), The Geology of Spain. Geological Society of London, London, pp. 155-183.

Antunes, I.M.H.R., 2006. Mineralogia, petrologia e geoquímica de rochas granitóides da área de Castelo Branco-Idanha-a-Nova. Unpublished PhD thesis University of Coimbra, $453 \mathrm{pp}$.

Antunes, I.M.H.R., Neiva, A.M.R., Silva, M.M.V.G., Corfu, F., 2008. Geochemistry of S-type granitic rocks from the reversely zoned Castelo Branco pluton (central Portugal). Lithos 103, 445-465.

Bea, F., Montero, P., González-Lodeiro, F., Talavera, C., 2007. Zircon inheritance reveals exceptionally fast crustal magma generation processes in Central Iberia during the Cambro-Ordovician. J. Petrol. 48, 2327-2339.

Beetsma, J.J., 1995. The late Proterozoic/Paleozoic and Hercynian crustal evolution of the Iberian Massif, northern Portugal. Unpublished PhD thesis, Faculty of Earth Sciences, Vrije Universiteit, Amsterdam, 233 pp.

Blundy, J.D., Wood, B.J., 1991. Crystal chemical controls on the partitioning of Sr and Ba between plagioclase, feldspar, silicate melts and hydrothermal solutions. Geochimica et Cosmochimica Acta 55, 193-210.

Blevin, P.L., Chappell, B.W., 1995. Chemistry, origin, and evolution of mineralized granites in the Lachlan fold belt, Australia; the metallogeny of I- and S-type granites. Econ. Geol. 90, 1604-1619.

Bogaerts, M., Scaillet, B., Liégeois, J.P., Vander Auwera, J., 2003. Petrology and geochemistry of the Lyngdal granodiorite (Southern Norway) and role of fractiona crystallisation in the genesis of Proterozoic ferro-potassic A-type granites. Precambrian Res. 124, 149-184.

Chappell, B.W., White, A.J.R., 1992. I- and S-type granites in the Lachlan Fold Belt. Trans. R. Soc. Edinb. Earth Sci. 83, 1-26.

Claoué-Long, J.C., Compston, W., Roberts, J., Fanning, C.M., 1995. Two Carboniferous ages: a comparison of SHRIMP zircon dating with conventional zircon ages and ${ }^{40} \mathrm{Ar} /{ }^{39} \mathrm{Ar}$ analysis. In: Berggren, W.A., Kent, D.V., Aubry, M.P., Werner, H.W. (Eds.) Geochronology, Time Scales and Global Stratigraphic Correlation. SEPM (Society for Sedimentary Geology) Special Publication, vol. 4, pp. 3-21.

Clarke, D.B., Dorais, M., Barbarin, B., Barker, D., Cesare, B., Clarke, G., El Baghdadi, M., Erdmann, S., Förster, H.-J., Gaeta, M., Gottesmann, B., Jamieson, R.A., Kontak, D.J., Koller, F., Gomes, C.L. London, D., Morgan VI, G.B., Neves, LJ.P.F., Pattison, D.R.M. Pereira, A.J.S.C., Pichavant, M., Rapela, C.W., Renno, A.D., Richards, S., Roberts, M., Rottura, A., Saavedra, J., Sial, A.N., Toselli, A.J., Ugidos, J.M., Uher, P., Villaseca, C., Visona, D., Whitney, D.L., Williamson, B., Woodard, H., 2005. Occurrence and origin of andalusite in peraluminous felsic igneous rocks. J. Petrol. 46, 441-472.

Cumming, G.L., Richards, J.R., 1975. Ore lead isotope ratios in a continuously changing earth. Earth Planet. Sci. Lett. 5, 27-34.

Dias, G., Simões, P.P., Ferreira, N., Leterrier, J., 2002. Mantle and crustal sources in the genesis of late-Hercynian granitoids (NW Portugal): geochemical and Sr-Nd isotopic constraints. Gondwana Res. 5, 287-305.

Dias, G., Leterrier, J., Mendes, A., Simões, P.P., Bertrand, J.M., 1998. U-Pb zircon and monazite geochronology of post- collisional Hercynian granitoids from the Central Iberian Zone (Northern Portugal). Lithos 45, 349-369.

Downes, H., Shaw, A., Williamson, B.J., Thirlwall, M.F., 1987. Sr, Nd a 136 (1997) 99-122 Hercynian granodiorites and monzogranites, Massif Central, France. Chem. Geol. 136, 99-122.

Finger, F., Roberts, M.P., Haunschmidt, B., Schermaier, A., Steyrer, H.P., 1997. Variscan granitoids of central Europe: their typology, potential sources and tectonothermal relations. Mineral. Petrol. 61, 67-96.

Frost, B.R., Barnes, C.G., Collins, W.J., Arculus, R.J., Ellis, D.J., Frost, C.D., 2001. A geochemical classification for granitic rocks. J. Petrol. 42, 2033-2048.

Gomes, M.E.P., Neiva, A.M.R., 2002. Petrogenesis of tin-bearing granites from Ervedosa, northern Portugal: the importance of magmatic processes. Chemie der Erde 62 47-72.

Govindaraju, K., Potts, P.J., Webb, P.C., Watson, J.S., 1994. Report on Whin sill dolerite WE- from England and Pitscurrie microgabbro PM-S from Scotland: assessment by one hundred and four international laboratories. Geostand. Newlett. 18, 211-300.

Haapala, I., 1997. Magmatic and postmagmatic processes in tin-mineralized granites: topaz-bearing leucogranite in the Eurajoki rapakivi granite stock, Finland. J. Petrol 38, 1645-1659.

Holtz, F., Barbey, P., 1991. Genesis of peraluminous granites. II. Mineralogy and chemistry of the Tourem complex (northern Portugal). Sequential melting vs. restite unmixing. J. Petrol. 32, 959-978.

Icenhower, J., London, D., 1995. An experimental study of element partitioning among biotite, muscovite and coexisting peraluminous silicic melt at $200 \mathrm{MPa}\left(\mathrm{H}_{2} \mathrm{O}\right) . \mathrm{Am}$. Mineral. 80, 1229-1251.

Ishihara, S., Sawata, H., Shibata, K., Terashima, S., Arrykul, S., Sato, K., 1980. Granites and Sn-W deposits of peninsular Thailand. Mining Geology Special Issue 8, 223-241.

Johannes, W., Holtz, F., 1996. Petrogenesis and Experimental Petrology of Granitic Rocks. Springer, Berlin. 335 pp.

Kawakami, T., 2001. Boron depletion accompanied by the breakdown of tourmaline in the magmatite-zone of the Aoyama area, Ryoke metamorphic belt, SW Japan: an implication for the formation of tourmaline leucogranites. Geological Society of America. Abstracts with Programs 336, 330.

Klein, T., Kihm, S., Siebel, W., Shang, C.K., Rohrmüller, J., Dörr, W., Zulauf, G., 2008. Age and emplacement of late-Variscan granites of the western Bohemian Massif with main focus on the Hauzenberg granitoids (European Variscides, Germany). Lithos 102, 478-507.

Lechler, P.J., Desilets, M.O., 1987. A review of the use of loss on ignition as a measurement of total volatiles in whole-rock analysis. Chem. Geol. 63, 341-344. 
Lehmann, B., 1982. Metallogeny of tin: magmatic differentiation versus geochemical heritage. Econ. Geol. 77, 50-59.

Lehmann, B., 1987. Tin granites, geochemical heritage, magmatic differentiation. Geol Rundsch. 76, 177-185.

Lehmann, B., 1990. Metallogeny of tin. Lecture Notes in Earth Sciences. Springer-Verlag, Berlin. 211 pp.

Le Maitre, R.W., Streckeisen, A., Zanettin, B., Le Bas, M.J., Bonin, B., Bateman, P., Bellieni, G., Dudek, A., Efremova, S., Keller, J., Lameyere, J., Sabine, P.A., Schmid, R., Sørensen, H., Wooley, A.R. (Eds.), 2003. Igneous Rocks. A Classification and Glossary Terms. Cambridge University Press. 236 p.

London, D., Burt, D.M., 1982. Chemical models for lithium aluminosilicate stabilites in pegmatite and granites. Am. Mineral. 67, 494-509.

Long, P.E., Luth, W.C., 1986. Origin of K-feldspar megacrysts in granitic rocks: implications of a partitioning model for barium. Am. Mineral. 71, 367-375.

Manning, D.A.C., 1981. The effect of fluorine on liquids phase relationships in the system Qz-Ab-Or with excess water at 1kb. Contrib. Mineral. Petrol. 76, 206-215.

Massone, H.-Y., Schreyer, W., 1987. Phengite geobarometry based on the limiting assemblage with K-feldspar, phlogopite and quartz. Contrib. Mineral. Petrol. 96, 212-224.

Massone, H.-Y., Szpurka, Z., 1997. Thermodynamic properties of white micas on the basis of high-pressure experiments in the systems $\mathrm{K}_{2} \mathrm{O}-\mathrm{MgO}-\mathrm{Al}_{2} \mathrm{O}_{3}-\mathrm{SiO}_{2}-\mathrm{H}_{2} \mathrm{O}$ and $\mathrm{K}_{2} \mathrm{O}-$ $\mathrm{FeO}-\mathrm{Al}_{2} \mathrm{O}_{3}-\mathrm{SiO}_{2}-\mathrm{H}_{2} \mathrm{O}$. Lithos 41, 229-250.

Miller, C.F., Stoddard, E.F., Bradfish, I.J., Dollase, W.A., 1981. Composition of plutonic muscovite: genetic implications. Can. Mineral. 19, 25-34.

Monier, G., Mergoil-Daniel, J., Labernardière, H., 1984. Générations successives de muscovites et feldspaths potassique dans les leucogranites du massif Millevaches (Massif Central Français). Bulletin de Minéralogie 107, 55-68.

Montero, P., Bea, F., 1998. Accurate determination of ${ }^{87} \mathrm{Rb} /{ }^{86} \mathrm{Sr}$ and ${ }^{147} \mathrm{Sm} /{ }^{144} \mathrm{Nd}$ by inductively coupled plasma mass spectrometry in isotope geoscience: an alternative to isotope dilution on analysis. Analytical Chimica Acta 358, 227-233.

Nachit, H., Razafimahefa, N., Stussi, J.M., Carron, J.P., 1985. Composition chimique des biotites et typologie magmatique des granitoides. Compte Rendus Academie de Sciences de Paris Série II 301 (11), 813-818.

Nash, W.P., Crecraft, H.R., 1985. Partition coefficients for trace elements in silicic magmas. Geochimica et Cosmochimica Acta 49, 2309-2322.

Neiva, A.M.R., 1984. Geochemistry of tin-bearing granitic rocks. Chem. Geol. 43, 241-256

Neiva, A.M.R., 1992. Geochemistry and evolution of Jales granite system, northern Portugal. Chemie der Erde 52, 225-241.

Neiva, A.M.R., 1993. Geochemistry of granites and their minerals from Gerez mountain, northern Portugal. Chemie der Erde 53, 227-258.

Neiva, A.M.R., 1998. Geochemistry of highly peraluminous granites and their minerals between Douro and Tamega valleys, northern Portugal. Chemie der Erde 58,161-184.

Neiva, A.M.R., 2002. Portuguese granites associated with Sn-W and Au mineralizations. Bull. Geol. Soc. Finl. 74, 79-101.

Neiva, A.M.R., Dodson, M.H., Rex, D.C., Guise, P.G., 1995. Radiometric constraints on hydrothermal circulation in cooling granite plutons. Miner. Depos. 30, 460-468.

Neiva, A.M.R., Neiva, J.M.C., Silva, M.M.V.G., 1990. Geochemistry of gold quartz vein walls from Jales (northern Portugal). Chem. Geol. 82, 217-251.

Neiva, A.M.R., Gomes, M.E.P., Ramos, J.M.F., Silva, P.B., 2008. Geochemistry of granitic aplite-pegmatite sills and their minerals from Arcozelo da Serra area (Gouveia, central Portugal). Eur. J. Mineral. 20, 465-485.
Patiño Douce, A.E.,1999. What do experiments tell us about the relative contributions of crust and mantle to the origin of granitic magmas? In: Castro, A., Fernández, C., Vigneress, Y.L. (Eds.), Understanding Granites: Integrating New and Classical Techniques. Geological Society of London, Special Publication, vol. 168, pp. 55-75.

Pereira, E., Ribeiro, A., Meireles, C., 1993. Cisalhamentos hercínicos e controlo das mineralizações de Sn-W, Au e U na Zona Centro-Ibérica, em Portugal. Cuadernos de Laboratorio Xeolóxico de Laxe 18, 89-119.

Pichavant, M., Manning, D., 1984. Petrogenesis of tourmaline granites and topaz granites; the contribution of experimental data. Phys. Earth Planet. Inter. 35, 31-50.

Ramos, J.M.F., 1998. Mineralizações de metais raros de Seixo Amarelo-Gonçalo (Guarda). Unpublished $\mathrm{PhD}$ thesis University of Lisbon, $659 \mathrm{pp}$.

Rieder, M., Cavazzini, G., D'Yakonov, Yu.S., Frank-Kamenetstii, V.A., Gottardi, G., Guggenheim, S., Koval, P.V., Müller, G., Neiva, A.M.R., Radoslovich, E.W., Robert, J.-L., Sassi, F.P., Takeda, H., Weiss, Z., Wones, D.R., 1999. Nomenclature of the micas. Mineral. Mag. 63, 267-279.

Sawka, W.N., Heizler, M.T., Kistler, R.W., Chappell, B.W., 1990. Geochemistry of highly fractionated I- and S-type granites from the tin-tungsten province of western Tasmania. The Geological Society of America Special Paper 246, 161-179.

Schärer, U., 1984. The effect of initial ${ }^{230}$ Th disequilibrium on young U-Pb ages: the Makalu case, Himalaya. Earth Planet. Sci. Lett. 67, 191-204.

Silva, M.M.V.G., Neiva, A.M.R., 1999/2000. Geochemistry of Hercynian peraluminous granites and their minerals from Carregal do Sal-Nelas-Lagares da Beira area, central Portugal. Chemie der Erde 59, 329-349.

Solomon, M.S., Groves, D., Jacques, A.L., 1994. The Geology and Origin of Australia's Mineral Deposits. Clarendon Press, Oxford. 951pp.

Steiger, R.H., Jäger, E., 1977. Subcommission on geochronology: convention on the use of decay constants in geo- and cosmochronology. Earth Planet. Sci. Lett. 36, 359-362.

Sylvester, P.Y., 1998. Post-collisional strongly peraluminous granites. Lithos 45, 29-44.

Tertian, R., Claisse, F., 1982. Principles of Quantitative X-ray Fluorescence Analysis. Heyden \& Son Ltd., U.K. 355 pp.

Valle Aguado, B., Azevedo, M.R., Schaltegger, U., Catalán, J.R., Nolan, J., 2005. U-Pb zircon and monazite geochronology of Variscan magmatism related to synconvergence extension in Central Northern Portugal. Lithos 82, 169-184.

White, A., 2003. High temperature applications. II: Oxygen isotopes as an indicator of assimilation. Geology 656 Isotope Geochemistry. Lecture 30, 227-231.

Williams, I.S., Buick, I.S., Cartwright, I., 1996. An extended episode of early Mesoproterozoic metamorphic fluid flow in the Reynolds Range, central Australia. J. Metamorphic Petrol. 14, 29-47.

Williamson, B.J., Shaw, A., Downes, H., Thirlwall, M.F., 1996. Chemical constraints on the genesis of Hercynian two-mica lencogranites from the Massif Central, France. Chem. Geol. 127, 25-42.

Yurimoto, H., Duke, E.F., Papike, J.J., Shearer, C.K., 1990. Are discontinuous chondritenormalized REE patterns in pegmatitic granitic systems the results of monazite fractionation? Geochimica et Cosmochimica Acta 54, 2141-2145.

Zeck, H.P., Whitehouse, M.Y., Ugidos, J.M., 2007. 496 \pm 3 Ma zircon ion microprobe age for pre-Hercynian granite, Central Iberian Zone, NE Portugal (earlier claimed 618 \pm 9 Ma). Geol. Mag. 144, 21-31. 